\title{
Article \\ New Bicyclic Azalide Macrolides Obtained by Tandem Palladium Catalyzed Allylic Alkylation/Conjugated Addition Reaction
}

\author{
Sulejman Alihodžić ${ }^{1}$, Hana Čipčić Paljetak ${ }^{2}$, Ana Čikoš ${ }^{3} \mathbb{D}$ and Ivaylo Jivkov Elenkov ${ }^{1, * \mathbb{D}}$ \\ 1 Department of Chemistry, Fidelta Ltd. (Selvita Group), Prilaz Baruna Filipovića 29, 10000 Zagreb, Croatia; \\ sulejman.alihodzic@fidelta.eu \\ 2 Center for Translational and Clinical Research, University of Zagreb School of Medicine, Šalata 2, \\ 10000 Zagreb, Croatia; hana.paljetak@mef.hr \\ 3 NMR Center, Ruđer Bošković Institute, Bijenička cesta 54, 10000 Zagreb, Croatia; ana.cikos@irb.hr \\ * Correspondence: ivaylo.elenkov@fidelta.eu
}

check for

updates

Citation: Alihodžić, S.; Čipčić

Paljetak, H.; Čikoš, A.; Elenkov, I.J.

New Bicyclic Azalide Macrolides

Obtained by Tandem Palladium

Catalyzed Allylic Alkylation/

Conjugated Addition Reaction.

Molecules 2022, 27, 432. https://

doi.org/10.3390/molecules27020432

Academic Editor: Ana Margarida

Gomes da Silva

Received: 10 December 2021

Accepted: 31 December 2021

Published: 10 January 2022

Publisher's Note: MDPI stays neutral with regard to jurisdictional claims in published maps and institutional affiliations.

Copyright: (C) 2022 by the authors. Licensee MDPI, Basel, Switzerland. This article is an open access article distributed under the terms and conditions of the Creative Commons Attribution (CC BY) license (https:// creativecommons.org/licenses/by/ $4.0 /)$.

\begin{abstract}
Unprecedented tandem allylic alkylation/intermolecular Michael addition was used in the preparation of novel bicyclic azalides. NMR spectroscopy was used not only to unambiguously determine and characterize the structures of these unexpected products of chemical reaction but also to investigate the effect the rigid bicyclic modification has on the conformation of the whole molecule. Thus, some of the macrolides prepared showed antibacterial activity in the range of well-known antibiotic drug azithromycin.
\end{abstract}

Keywords: macrolides; azalides; bicyclolides; tandem reaction; allylation; NMR spectroscopy; conformational analysis

\section{Introduction}

Polyketide macrolides are widely distributed natural products many of which became important medicines in treatment of infectious and neoplastic conditions. In most cases, these compounds contain polyhydroxy macrocyclic lactone glycosylated with one or more sugar moieties [1-3]. Erythromycin, a typical representative of this group, was discovered in the 1950s and quickly became commonly used agent in treatment of respiratory and soft tissue infections (Figure 1). Issues with fast growing bacterial resistance, acid instability, and gastro-intestinal side effects led to developments of new, improved, semi-synthetic analogues. Thus, clarithromycin [4] and azithromycin [5] were discovered in the 1980s, followed by ketolides a decade later [6]. Furthermore, linking two or three suitably oriented functionalities by a bridge allowed formation of conformationally rigid condensed polycyclic structures [7] known as bicyclolides [8-11]. Today, the macrolides are studied, or have already found application, as immunomodulators [12], anti-parasitic agents [13,14], or even in treatment of COVID-19 [15]. Some of them even found application in non-medicinal environment, as chiral selectors in liquid chromatography and capillary electrophoresis [16].

In the course of our search for macrolides with novel biological profiles, we investigated the possibilities for regioselective introduction of (hetero)aryl moiety at position 9a in azalide molecule via C2-4-spacer. Soon, it became obvious that presence and position of the heteroatom in the aromatic system had a profound effect on the outcome of the reaction. Herein, we report unprecedented, highly diastereoselective one-pot-twostep preparation of bicyclic azalides, which are products of tandem palladium, catalyzed allylation/intermolecular conjugate addition reaction. 


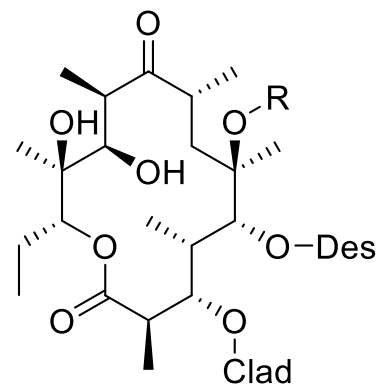

Erythromycin $A(\mathrm{R}=\mathrm{H})$ Clarithromycin $(\mathrm{R}=\mathrm{Me})$<smiles>C1=CC[N+]=C1</smiles><smiles>C=NNc1ccc(CCl)cn1</smiles><smiles>C1CCCCC1</smiles><smiles>CC(N)=O</smiles>

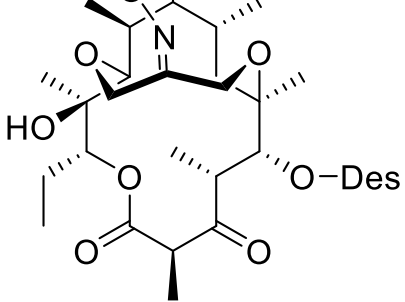

EPD-420

(bicyclolide)

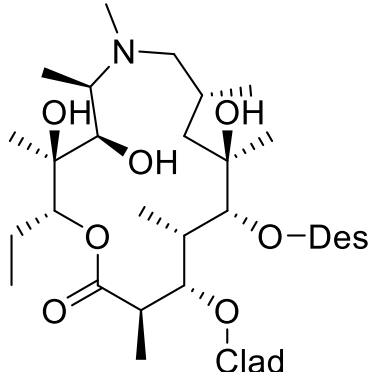

Azithromycin (azalide)

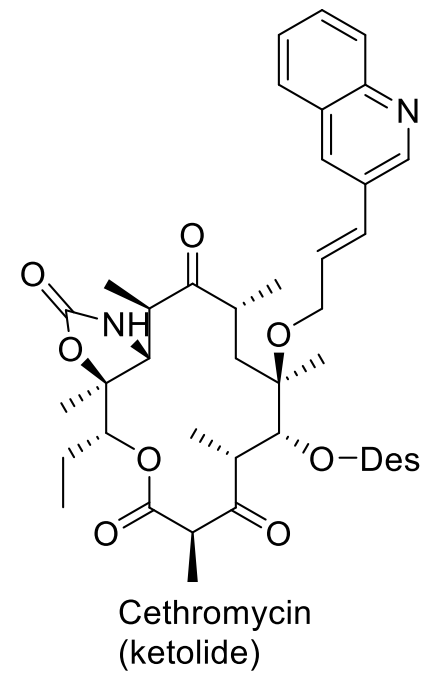

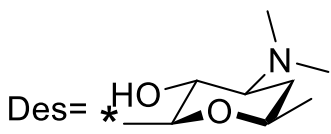

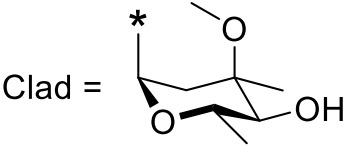

Figure 1. Overview of important of polyketide macrolides.

\section{Results and Discussion}

We envisioned activated 3-quinolyl-allyl alcohols as suitable building blocks for our target molecules, that were to contain quinoline units bound to 9a position of the azalide via C3-linker. Quinolyl analogues of cinnamic alcohol are easily obtainable and excellent substrates for palladium catalyzed allylation of amines and alcohols, a method widely used in total and new chemical entities (NCE) syntheses $[17,18]$. We started our investigations with the azalide $\mathbf{1}$, a precursor in the synthesis of azithromycin and 3-quinolyl-derivative $\mathbf{2}$, an intermediate in preparation of cethromycin [19]. The reaction was highly chemo- and stereoselective, affording 3 in $87 \%$ yields as a trans isomer only (Scheme 1). 


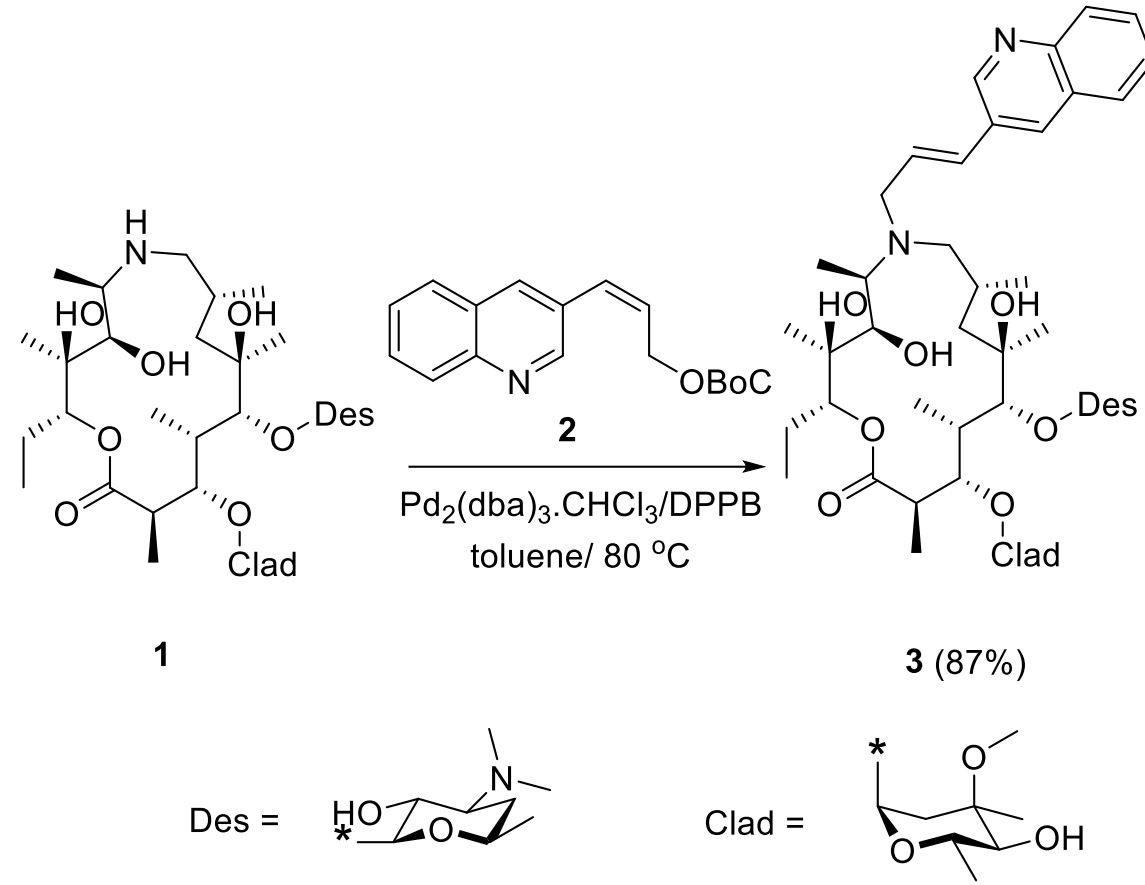

Scheme 1. 9a-allylation of compound 1.

Nucleophilic addition of the amine to the $\pi$-allyl-palladium complex seems to be much slower than its $\pi-\sigma-\pi$-interconversion, thus allowing complete transfer of cis-alkene geometry of 2 into trans-one in 3 [20].

Allyl carbonates $\mathbf{8 a}$ and $\mathbf{8 b}$ were prepared as analogues of $\mathbf{2}$ in a three-step sequence of Wittig olefination, reduction [21,22], and BoC activation (Scheme 2). Allylation of 1 with isomeric $\mathbf{8 a}$ and $\mathbf{8 b}$ proceeded smoothly, and products were isolated in acceptable yields (Scheme 3).

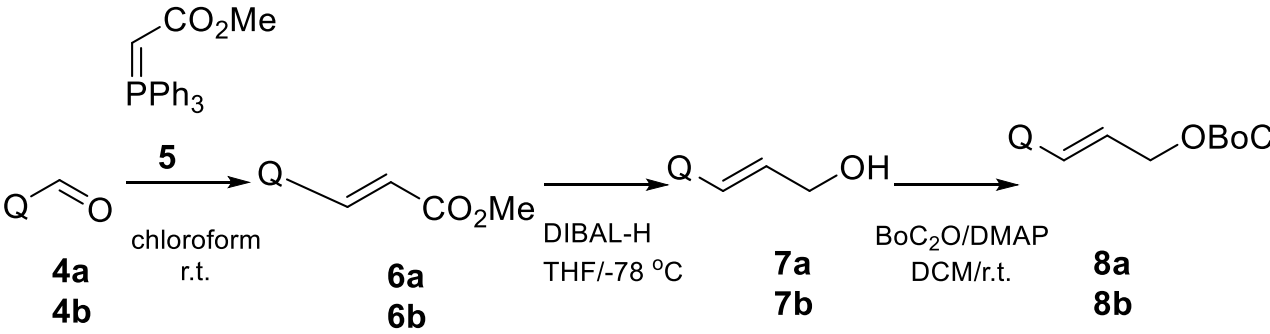

Scheme 2. Preparation of allyl carbonates $8 \mathbf{a}$ and $8 \mathbf{b} . \mathrm{Q}=2$-quinolyl (4a, 6a, 7a, 8a), $\mathrm{Q}=4$-quinolyl $(4 b, 6 b, 7 b, 8 b)$.

The NMR analysis, however, showed that the spectra did not match the expected products $9 \mathbf{a}$ and $\mathbf{9 b}$. In the ${ }^{1} \mathrm{H}-\mathrm{NMR}$, instead of olefin signals, two pairs of diastereotopic protons were observed, as well as the signal at $4.27 \mathrm{ppm}$, corresponding to a new carbinol center. More thorough analysis of 2D NMR spectra revealed the formation of the bicyclic compounds 10a and 10b, evidently products of tandem allylation/conjugated addition reaction. The formation of a six-membered ring perfectly explains the observed downfield shifts of ca 5 ppm for C-11 (74.2 ppm in $3 \rightarrow 78.9$ ppm in 10a and 79.0 ppm in 10b), as well as upfield shifts of ca 5 ppm for C-10 (62.0 ppm in $3 \rightarrow 56.6$ ppm in 10a and 56.7 ppm in $\mathbf{1 0 b}$ ). 


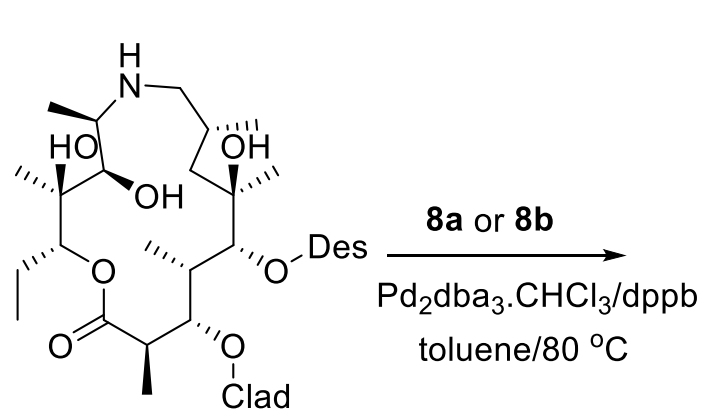

1

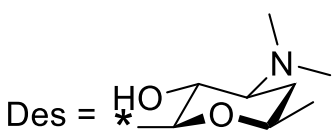

Clad $=2_{O}^{*} \mathrm{OH}$

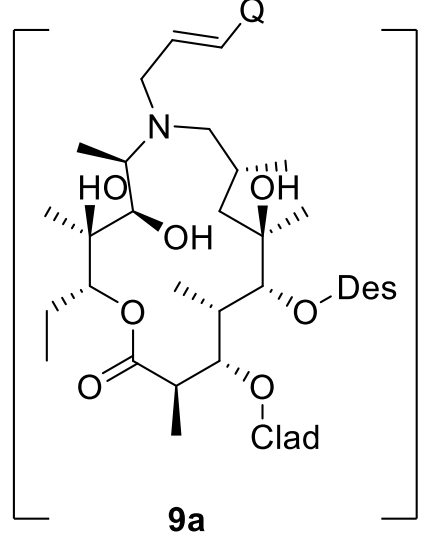

$9 b$

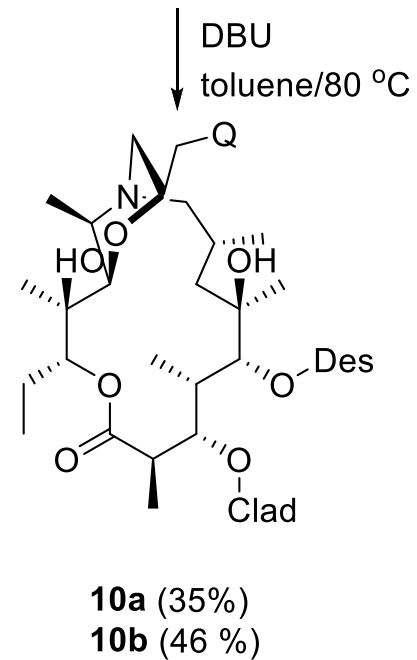

Scheme 3. Allylation of $\mathbf{1}$ with $8 \mathbf{a}$ and $\mathbf{8 b}$.

A possible rationale for such event is the activation of the allyl double bond by the electron-poor 2- and 4-quinolyl rings. Traces of a base (amines present in the mobile phase used in the purification step) triggered addition of nucleophilic 11-OH group to the proximal activated double bond, affording a new morpholine ring. This annulation was successfully performed in one-pot procedure. Addition of catalytic amounts of DBU after the completion of allylation process gave 10a and 10b, again in acceptable yields. Retro-allylation, however, was the main side reaction leading back to 1 .

If it is assumed that cyclization process is a conjugated addition, then the presence of suitably oriented electron-withdrawing group (EWG) in the allyl donor is essential for the success of cyclization. Both 2-and 4-quinolinyl moieties polarize and activate the allyl double bond, thus making it a good acceptor in 1,4 and 1,6-addition, respectively. 3-Quinolyl, on the other hand, does not activate the double bond. Therefore, 3 , as expected, did not form cyclization product, even after prolonged heating in the presence of 1 equivalent of DBU.

Since a new chiral center (C-22) is formed in the course of the reaction, NOE and coupling constant analyses were performed in order to determine its stereochemistry. Possible impact of the newly formed morpholine ring on the conformation of the macrocycle and sugar moieties of 10a and $\mathbf{1 0 b}$ (deuterated chloroform) was also investigated. In both compounds, the stereochemistry at C-22 was determined to be $R$ using strong NOE interactions between protons $\mathrm{H}-22 / \mathrm{H}-11, \mathrm{H}-22 / 6-\mathrm{OH}$, and 6-OH/H-11 (Figure 2b). Such NOE interactions are possible only if $\mathrm{H}-22$ and $\mathrm{H}-11$ are both pseudo-axial in a chair conformation of the newly formed morpholine ring (Figure 2a). This was corroborated by a large coupling constant between H-22 and H-23ax (10.7 Hz for 10a and $10.8 \mathrm{~Hz}$ for 10b), 
as well as small coupling constant between $\mathrm{H}-22$ and $\mathrm{H}-23 \mathrm{eq}(2.9 \mathrm{~Hz}$ for 10a and $3.7 \mathrm{~Hz}$ for 10b), as seen in Table S1, Supplementary Materials. Downfield chemical shift of 6-OH (5.7 ppm) indicates a hydrogen bond with the chiral nitrogen at 9a occupying a pseudo-axial position, as well. Similar observations on 6-OH were reported for other conformationally restricted bicyclic azalides, where $N-9$ a and $O-12$ were part of the 1,3-oxazine ring [23].

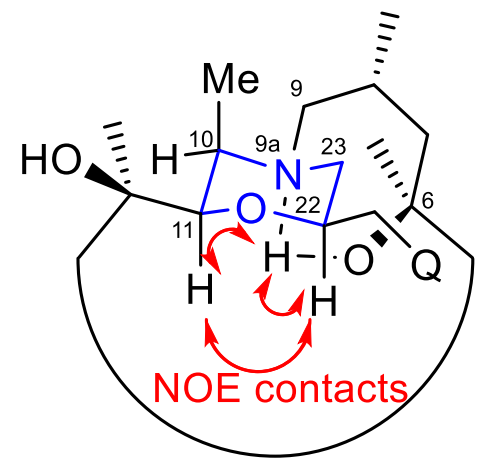

(a)

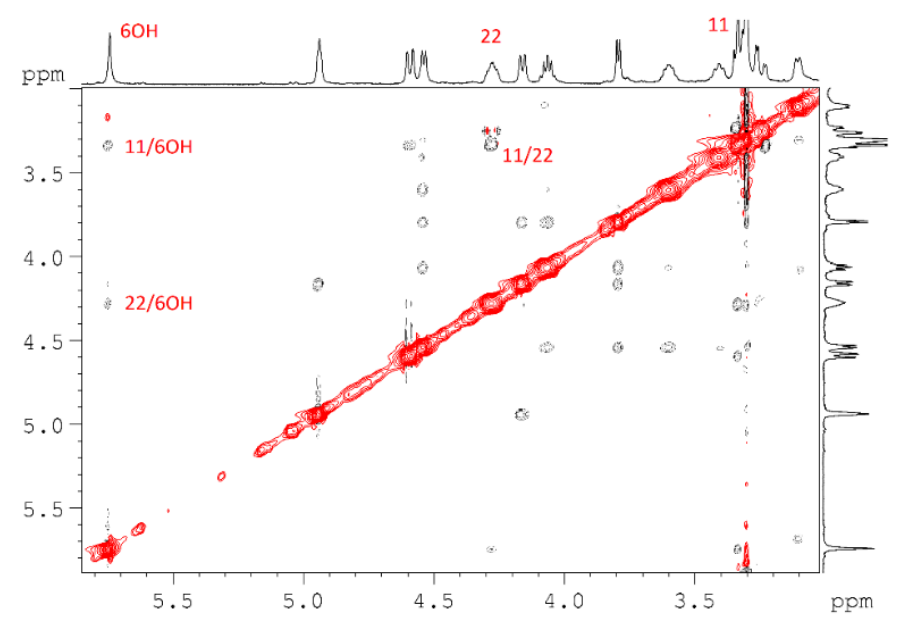

(b)

Figure 2. (a) NOE contacts observed in the (b) NOESY NMR spectrum of $\mathbf{1 0 b}$ confirming the $\mathrm{R}$ configuration of $\mathrm{C}-22$.

Previous conformational studies on macrolides have established that the macrolactone can adopt two types of conformations (folded-in and folded-out), distinguished by the outward or inward folding of the C-3 to C-5 region [24,25]. Coupling constants ${ }^{3} J_{\mathrm{H}-2, \mathrm{H}-3}$ in both 10a and $10 \mathrm{~b}$ have a value of ca $9 \mathrm{~Hz}$, and their NOESY spectra display strong H-4/H-11 interactions (Supplementary Materials), which establishes that these bicyclic macrolides in chloroform, unlike monocyclic azithromycin [25], adopt an energetically more favorable folded-out conformation. Both sugar moieties, on the other hand, adopt the natural Everett-Tyler chair conformation [24] and keep their usual orientation with respect to the macrocycle.

In both 10a and 10b, the quinolyl moiety exhibits only one strong non-trivial NOE contact (H-3 of the heterocycle with $\mathrm{H}-13$ from the macrocycle), suggesting that this group is positioned above the "western" part of the macrocycle.

We still cannot firmly state what impact double bond geometry in $\mathbf{8}$ has on the stereoselectivity of the cyclization. We assume however, that faster $\pi-\sigma-\pi$-interconversion of the $\pi$-ally-palladium complex leads to formation of plausible trans intermediates 9a or 9b. Evidently, the annulation is possible in a conformation where the whole side chain 
is oriented over the "plane" of the macrolide aglycon with double bond and 11-OH in close proximity. $22 R$-isomer is obviously thermodynamically more stable with an aromatic substituent in pseudo-equatorial position.

Expanding the scope of the reaction, we prepared EWG activated allylic carbonates $14 \mathrm{a}$ and $14 \mathrm{~b}$ in a two-step procedure (Scheme 4 ). Wittig condensation of dimeric hydroxyacetaldehyde (11) with commercially available phosphonium ylides 5 and $\mathbf{1 2}$ afforded allyl alcohols 13a [26] and $\mathbf{1 3 b}$ in excellent yields. Their activation with $\mathrm{BoC}_{2} \mathrm{O}$ afforded carbonates 14a and 14b in very good yields, as well. It is worth mentioning that, in the case of $\mathbf{1 3 b}$, the olefination had low stereoselectivity that reflected in the 2:3 trans/cis mixture in $14 b$.

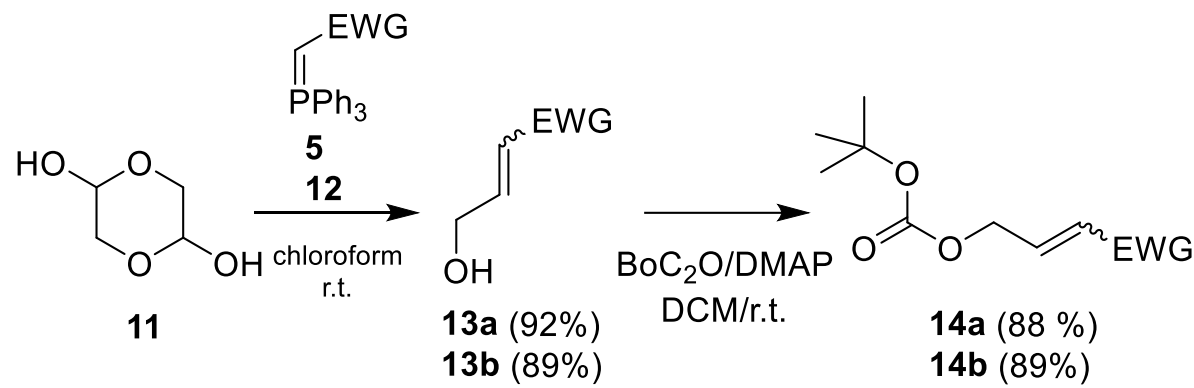

Scheme 4. Preparation of allyl carbonates 14a and $14 \mathbf{b}$. EWG $=\mathrm{CO}_{2} \mathrm{Me}(\mathbf{5}, \mathbf{1 3 a}, \mathbf{1 4 a}), \mathrm{EWG}=\mathrm{CN}(\mathbf{1 2}$, $13 b, 14 b)$.

One-pot tandem allylation/Michael addition reaction of these new allyl carbonates with azalide $\mathbf{1}$ afforded $\mathbf{1 5 a}$ and $\mathbf{1 5 b}$ in good yields with the same high stereocontrol (Scheme 5). It is worth noting that, even though $\mathbf{1 4} \mathbf{b}$ was used as a mixture of cis/trans isomers (3:2), no change in reaction stereoselectivity was observed. Fast $\pi-\sigma-\pi$-interconversion before $\mathrm{N}$-allylation cannot be excluded (vide supra).

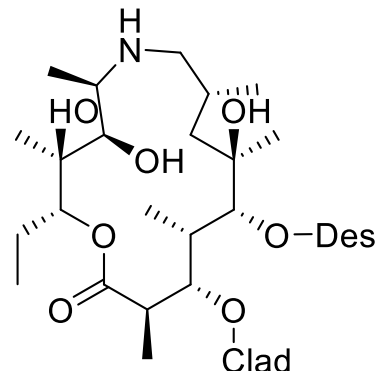
1
$14 a$ or $14 b$

1) $\mathrm{Pd}_{2} \mathrm{dba}_{3} \cdot \mathrm{CHCl}_{3} / \mathrm{DPPB}$

toluene $/ 80^{\circ} \mathrm{C}$

2) $\mathrm{DBU}$

toluene $/ 80^{\circ} \mathrm{C}$

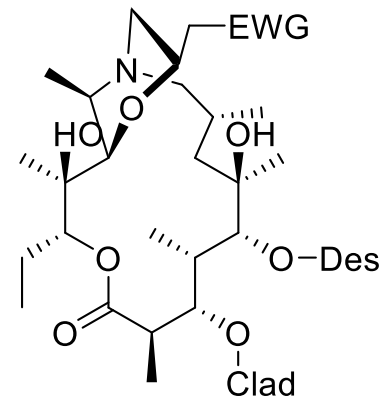

$15 a(35 \%)$

$15 b(46 \%)$

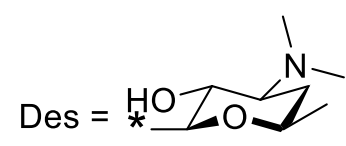

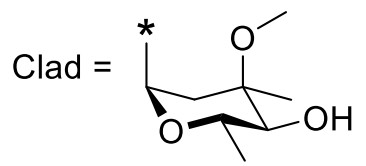

Scheme 5. Preparation of $15 a\left(E W G=\mathrm{CO}_{2} \mathrm{Me}\right)$ and $15 b(E W G=C N)$.

Literature analysis demonstrated that similar bridging of $\mathrm{N}-9 \mathrm{a}$ and $11-\mathrm{OH}$ group of the azalides via tandem diallylation of $\mathbf{1}$ was previously reported [27]. Although the obtained bicyclic products had the same carbon skeleton as the one reported here, the stereoselectivity of double allylation was low, giving mixtures of 1:1-1:2 of the possible diastereoisomers. 
Antibacterial activities of the prepared macrolides were tested against a panel of relevant Gram-positive (Streptococcus pneumoniae, Streptococcus pyogenes, and Staphylococcus aureus) and Gram-negative (Haemophilus influenzae and Moraxella catarrhalis) bacterial respiratory tract pathogens that were either sensitive or resistant to macrolide antibiotics. The results, expressed as minimum inhibitory concentrations (MICs), are shown in Table 1, alongside azithromycin as a comparator. Quinolyl derivatives $10 \mathrm{a}$ and $\mathbf{1 0 b}$ were fully active against eryS Gram-positive species, while $\mathbf{1 5 a}$ and $\mathbf{1 5 b}$ were not as potent against $S$. aureus.

Table 1. Antibacterial activities of synthesized macrolides. Bacteria tested are standard strains available from ATCC collection, as well as clinical isolates that are either sensitive to macrolide antibiotics, or have well-characterized macrolide resistance mechanisms.

\begin{tabular}{|c|c|c|c|c|c|c|c|}
\hline \multirow{2}{*}{\multicolumn{2}{|c|}{ Microorganism }} & \multicolumn{6}{|c|}{$\operatorname{MIC}(\mu \mathrm{g} / \mathrm{mL})$} \\
\hline & & \multirow{2}{*}{$\begin{array}{c}\text { Azithromycin } \\
\leq 0.125\end{array}$} & \multirow{2}{*}{$\begin{array}{c}3 \\
\leq 0.125\end{array}$} & \multirow{2}{*}{$\begin{array}{c}\mathbf{1 0 a} \\
\leq 0.125\end{array}$} & \multirow{2}{*}{$\begin{array}{c}\mathbf{1 0 b} \\
\leq 0.125\end{array}$} & \multirow{2}{*}{$\begin{array}{c}15 a \\
\leq 0.125\end{array}$} & \multirow{2}{*}{$\begin{array}{c}\mathbf{1 5 b} \\
\leq 0.125\end{array}$} \\
\hline S. pneumoniae SP030 & ery $S$ & & & & & & \\
\hline S. pyogenes 3565 & ery $S$ & $\leq 0.125$ & $\leq 0.125$ & $\leq 0.125$ & $\leq 0.125$ & 0.25 & 0.25 \\
\hline S. aureus ATCC13709 & ery $S$ & 0.5 & 0.25 & $\leq 0.125$ & 0.25 & 4 & 8 \\
\hline S. pneumoniae Ci137 & $\mathrm{M}$ & 8 & 8 & 4 & 16 & 32 & 32 \\
\hline S. pyogenes Finland 2 & M & 8 & 4 & 2 & 4 & 16 & 8 \\
\hline S. aureus PK1 & M & $>64$ & $>64$ & $>64$ & $>64$ & $>64$ & $>64$ \\
\hline S. pneumoniae 134 GR-M & iMcLS & $>64$ & $>64$ & $>64$ & $>64$ & $>64$ & $>64$ \\
\hline S. pyogenes Finland 11 & iMLS & 16 & 2 & 0.5 & 4 & $>64$ & $>64$ \\
\hline S. aureus PK2 & iMLS & $>64$ & $>64$ & $>64$ & $>64$ & $>64$ & $>64$ \\
\hline M. catarrhalis ATCC 49247 & & $\leq 0.125$ & 1 & 4 & 4 & 0.5 & 1.25 \\
\hline H. influenzae ATCC 23246 & & 1 & 2 & 4 & 4 & 4 & 4 \\
\hline
\end{tabular}

These two compounds have similar potency and retain good activity against Gramnegative bacteria, but their activity against erythromycin resistant pathogens is weak. It should be noted, however, that EWG present in these molecules (ester in 15a and nitrile in 15b) are excellent handles for further transformations and derivatizations that might lead to improved antibacterial activities. To summarize, attached quinolyl moiety influences the antibacterial properties; thus, overall, 10a is the most potent compound, with improved activity over Azithromycin, especially regarding iMLS S. pyogenes (MICs of $0.5 \mu \mathrm{g} / \mathrm{mL}$ versus $16 \mu \mathrm{g} / \mathrm{mL})$. However, activity against $M$. catarrhalis $(4 \mu \mathrm{g} / \mathrm{mL})$ remains unsatisfactory.

\section{Experimental Section}

\subsection{General Methods}

All reactions utilizing air- and moisture-sensitive reagents were performed in dried glassware under an atmosphere of dry argon or nitrogen. Commercially available reagents and catalysts were purchased from Sigma-Aldrich (Saint Louis, MO, USA), Fluka (Saint Louis, MO, USA), and Merck (Darmstadt, Germany) and were used without additional purifications. Anhydrous solvents were purchased in Sure Seal bottles from Aldrich and used via standard syringe techniques. Compound 1 was purchased from PLIVA as a hydrate and was azeotropically dried by dissolving in toluene and removal of the solvent under reduced pressure. Compound.2 1 was prepared as previously described.

All solvents used for chromatography were technical grade. For thin-layer chromatography (TLC) analysis, Merck pre-coated glass plates (TLC Silica gel 60 F254) were used. TLC spots were visualized either under UV light (at 254 or $366 \mathrm{~nm}$ ) or by spraying with $5 \%$ ethanolic sulfuric acid and subsequent charring. SPE purifications were performed on commercially available cartridges (LC-Silica Packing) and were purchased from Supelco (Saint Louis, MO, USA). Mixtures of DCM and increasing amounts of 3\% methanolic ammonia were used as mobile phase.

All solvents used for NMR sample preparation were purchased from EurIsotop (SaintAubin, France). NMR spectra were recorded on Bruker Avance III 600, Bruker Avance DRX500, Bruker Avance AV400, and Bruker Avance DPX300 spectrometers (Billerica, MA, 
USA), equipped with $5 \mathrm{~mm}$ diameter broadband inverse and ${ }^{1} \mathrm{H} /{ }^{13} \mathrm{C}$ dual detection probes with z-gradient accessory. The spectra were acquired using standard Bruker pulse sequences on samples dissolved in deuterated chloroform $\left(\mathrm{CDCl}_{3}\right)$ with TMS as the internal standard and at $25^{\circ} \mathrm{C}$. NOESY spectra were obtained with the mixing time of $400 \mathrm{~ms}$.

HRMS spectra were acquired as accurate mass centroided data using a Micromass Q-Tof 2 hybrid quadrupole time-of-flight mass spectrometer, equipped with a Z-spray interface, over a mass range of $100-1100 \mathrm{Da}$, with a scan time of $0.9 \mathrm{~s}$ and an interscan delay of $0.1 \mathrm{~s}$. Reserpine was used as the external mass calibrant $([\mathrm{M}+\mathrm{H}]+=609,2812 \mathrm{~m} / \mathrm{z})$. The Q-Tof 2 mass spectrometer was operated in $\mathrm{W}$ reflection mode to give a resolution (FWHM) of $16,000-20,000$. Ionization was achieved with a spray voltage of $3.2 \mathrm{kV}$, a cone voltage of $50 \mathrm{~V}$, with cone and desolvation gas flows of 10-20 and $600 \mathrm{~L} / \mathrm{h}$, respectively. The source block and desolvation temperatures were maintained at $120^{\circ} \mathrm{C}$ and $250{ }^{\circ} \mathrm{C}$, respectively. The elemental composition was calculated using MassLynx v4.1 for the $[\mathrm{M}+\mathrm{H}]+$.

Antimicrobial activity was tested against relevant Gram-positive (S. pneumoniae, S. pyogenes, and S. aureus) and Gram-negative (H. influenzae, M. catarrhalis) bacterial respiratory tract pathogens that were either sensitive or resistant to macrolide antibiotics, due to expression of efflux pumps (M phenotype) or inducible ribosome methylation (iMLSb phenotype).

MICs were determined by the broth microdilution method [28], except that, in the medium used to grow Streptococcus strains, lysed blood was replaced by $5 \%$ horse serum. The compounds were dissolved in dimethyl sulfoxide (DMSO) at a concentration of $5 \mathrm{mg} / \mathrm{mL}$ and azithromycin was used as control. Bacteria for inoculum preparation were grown on appropriate agar plates (Becton Dickinson, Franklin Lakes, NJ, USA): Columbia agar with 5\% sheep blood for Streptococci and M. catarrhalis, chocolate agar for H. influenzae, and Mueller-Hinton agar for Staphylococci.

\subsection{Synthetic Procedures}

9-Deoxo-9a-(3-(3-Quinolyl)-2-propenyl)-9a-aza-9a-homoerythromycin A (3)

A flame-dried Schlenk tube was charged under argon with $\mathrm{Pd}_{2}(\mathrm{dba})_{3} \cdot \mathrm{CHCl}_{3}(5.18 \mathrm{mg}$, $5.00 \mu \mathrm{mol})$, DPPB $(4.26 \mathrm{mg}, 10.00 \mu \mathrm{mol})$, and toluene $(5 \mathrm{~mL})$. The reaction mixture was stirred at ambient temperature for $10 \mathrm{~min}$. Then, $1(0.367 \mathrm{~g}, 0.5 \mathrm{mmol})$ and $2(0.185 \mathrm{~g}$, $0.65 \mathrm{mmol}$ ) were added, and the reaction mixture was stirred at $80{ }^{\circ} \mathrm{C}$ for $1.5 \mathrm{~h}$. After cooling to ambient temperature, it was diluted with water $(50 \mathrm{~mL})$. $\mathrm{pH}$ was lowered to 2 , and layers were separated. $\mathrm{pH}$ of the aqueous extract was gently increased to $\mathrm{pH} 7.4$ with $1 \mathrm{pH}$ unit step. An extraction with DCM $(30 \mathrm{~mL})$ was performed each time. The combined fractions containing the title product were evaporated to dryness. Crude product was purified by SPE. The title product was obtained as pale beige foam $(392 \mathrm{mg}, 87 \%)$.

${ }^{1} \mathrm{H}-\mathrm{NMR}\left(400 \mathrm{MHz}, \mathrm{CDCl}_{3}\right) \delta: 8.95(\mathrm{~s}, 1 \mathrm{H}), 8.10(\mathrm{~s}, 1 \mathrm{H}), 8.04(\mathrm{~d}, J=8.4 \mathrm{~Hz}, 1 \mathrm{H}), 7.76$ $(\mathrm{d}, J=8.3 \mathrm{~Hz}, 1 \mathrm{H}), 7.63(\mathrm{t}, J=7.6 \mathrm{~Hz}, 1 \mathrm{H}), 7.45-7.54(\mathrm{~m}, 1 \mathrm{H}), 6.65-6.75(\mathrm{~m}, 1 \mathrm{H}), 6.58(\mathrm{~d}$, $J=16.1 \mathrm{~Hz}, 1 \mathrm{H}), 5.04(\mathrm{~d}, J=4.5 \mathrm{~Hz}, 1 \mathrm{H}), 4.69(\mathrm{~d}, J=8.9 \mathrm{~Hz}, 1 \mathrm{H}), 4.43(\mathrm{~d}, J=7.3 \mathrm{~Hz}, 1 \mathrm{H})$, $4.18-4.23(\mathrm{~m}, 1 \mathrm{H}), 4.04-4.14(\mathrm{~m}, 1 \mathrm{H}), 3.97(\mathrm{dd}, J=13.2,3.8 \mathrm{~Hz}, 1 \mathrm{H}), 3.83$ (brs, $1 \mathrm{H}), 3.68$ $(\mathrm{d}, J=6.7 \mathrm{~Hz}, 1 \mathrm{H}), 3.45-3.54(\mathrm{~m}, 1 \mathrm{H}), 3.41(\mathrm{dd}, J=14.3,7.6 \mathrm{~Hz}, 1 \mathrm{H}), 3.31(\mathrm{~s}, 3 \mathrm{H}), 3.22(\mathrm{dd}$, $J=9.2,7.8 \mathrm{~Hz}, 1 \mathrm{H}), 3.04(\mathrm{t}, J=8.7 \mathrm{~Hz}, 1 \mathrm{H}), 2.78-2.92(\mathrm{~m}, 3 \mathrm{H}), 2.40-2.52(\mathrm{~m}, 1 \mathrm{H}), 2.35(\mathrm{~d}$, $J=15.1 \mathrm{~Hz}, 1 \mathrm{H}), 2.28(\mathrm{~s}, 6 \mathrm{H}), 2.19(\mathrm{~d}, J=10.9 \mathrm{~Hz}, 1 \mathrm{H}), 1.96-2.16(\mathrm{~m}, 3 \mathrm{H}), 1.80-1.94(\mathrm{~m}, 1 \mathrm{H})$, $1.72(\mathrm{~d}, J=14.7 \mathrm{~Hz}, 1 \mathrm{H}), 1.65(\mathrm{~d}, J=11.8 \mathrm{~Hz}, 1 \mathrm{H}), 1.60(\mathrm{dd}, J=15.0,5.2 \mathrm{~Hz}, 1 \mathrm{H}), 1.44-1.54$ $(\mathrm{m}, 1 \mathrm{H}), 1.37-1.43(\mathrm{~m}, 1 \mathrm{H}), 1.34(\mathrm{~d}, J=6.4 \mathrm{~Hz}, 3 \mathrm{H}), 1.32(\mathrm{~s}, 3 \mathrm{H}), 1.27-1.30(\mathrm{~m}, 1 \mathrm{H}), 1.23(\mathrm{~s}$, $3 \mathrm{H}), 1.21(\mathrm{~d}, J=7.2 \mathrm{~Hz}, 3 \mathrm{H}), 1.18(\mathrm{~d}, J=6.2 \mathrm{~Hz}, 3 \mathrm{H}), 1.08(\mathrm{~s}, 3 \mathrm{H}), 1.06(\mathrm{~d}, J=5.7 \mathrm{~Hz}, 3 \mathrm{H})$, $0.89(\mathrm{t}, J=7.3 \mathrm{~Hz}, 3 \mathrm{H}), 0.85(\mathrm{~d}, J=6.9 \mathrm{~Hz}, 3 \mathrm{H}) ;{ }^{13} \mathrm{C}-\mathrm{NMR}\left(101 \mathrm{MHz}, \mathrm{CDCl}_{3}\right) \delta: 178.2(\mathrm{C})$, $149.6(\mathrm{CH}), 147.4(\mathrm{C}), 132.1(\mathrm{CH}), 131.3(\mathrm{CH}), 130.0(\mathrm{C}), 129.1(\mathrm{CH}), 129.0(\mathrm{CH}), 128.6(\mathrm{CH})$, 128.1 (C), 127.8 (CH), $126.8(\mathrm{CH}), 103.0(\mathrm{CH}), 95.4(\mathrm{CH}), 83.7(\mathrm{CH}), 78.7(\mathrm{CH}), 78.0(\mathrm{CH}), 77.7$ (C), $74.7(\mathrm{C}), 74.4(\mathrm{CH}), 74.2(\mathrm{C}), 72.8(\mathrm{CH}), 70.8(\mathrm{CH}), 68.8(\mathrm{CH}), 65.9(\mathrm{CH}), 65.7(\mathrm{CH}), 65.6$ $\left(\mathrm{CH}_{2}\right), 62.0(\mathrm{CH}), 53.8\left(\mathrm{CH}_{2}\right), 49.4\left(\mathrm{CH}_{3}\right), 45.0(\mathrm{CH}), 41.4\left(\mathrm{CH}_{2}\right), 41.0(\mathrm{CH}), 40.3\left(2 \mathrm{CCH}_{3}\right)$, $34.9\left(\mathrm{CH}_{2}\right), 28.8\left(\mathrm{CH}_{2}\right), 28.3(\mathrm{CH}), 27.0\left(\mathrm{CH}_{3}\right), 22.1\left(\mathrm{CH}_{3}\right), 21.5\left(\mathrm{CH}_{3}\right), 21.4\left(\mathrm{CH}_{2}\right), 21.3\left(\mathrm{CH}_{3}\right)$, 
18.3 $\left(\mathrm{CH}_{3}\right), 16.3\left(\mathrm{CH}_{3}\right), 15.1\left(\mathrm{CH}_{3}\right), 11.2\left(\mathrm{CH}_{3}\right), 9.4\left(\mathrm{CH}_{3}\right), 9.3\left(\mathrm{CH}_{3}\right)$; HRMS (ES $)$ Calc. for $\mathrm{C}_{49} \mathrm{H}_{80} \mathrm{~N}_{3} \mathrm{O}_{12}\left([\mathrm{M}+\mathrm{H}]^{+}\right)$: 902.5742; found: 902.5741 .

Methyl 3-(2-quinolynyl)-Acrylate (6a)

Compounds $4 \mathrm{a}(1.1 \mathrm{~g}, 7 \mathrm{mmol})$ and $5(2.34 \mathrm{~g}, 7 \mathrm{mmol})$ were suspended in chloroform $(50 \mathrm{~mL})$. The reaction mixture was stirred at ambient temperature overnight. The red solution was extracted with $1 \mathrm{~N} \mathrm{HCl}(2 \times 20 \mathrm{~mL})$. The combined aqueous extracts were washed with EtOAc $(20 \mathrm{~mL})$ and neutralized with $10 \% \mathrm{NaOH}$. Extraction with EtOAc $(3 \times$ $20 \mathrm{~mL}$ ) afforded organic solution of the title product that was washed with brine $(20 \mathrm{~mL})$, dried over $\mathrm{Na}_{2} \mathrm{SO}_{4}$, and the solvent was evaporated. Thus, the red oil formed was passed through a plug of $\mathrm{SiO}_{2}(50 \mathrm{~g})$ and eluted with Hexanes:EtOAc (10:1). The title product was obtained as yellowish oil that slowly solidified $(1.13 \mathrm{~g}, 75 \%)$.

${ }^{1} \mathrm{H}-\mathrm{NMR}(300 \mathrm{MHz}, \mathrm{CDCl})$ ) $8: 8.18(\mathrm{~d}, J=8.4 \mathrm{~Hz}, 1 \mathrm{H}), 8.12(\mathrm{~d}, J=8.3 \mathrm{~Hz}, 1 \mathrm{H}), 7.91(\mathrm{~d}$, $J=15.9 \mathrm{~Hz}, 1 \mathrm{H}), 7.82(\mathrm{~d}, J=8.2 \mathrm{~Hz}, 1 \mathrm{H}), 7.74(\mathrm{ddd}, J=8.4,7.0,1.4 \mathrm{~Hz}, 1 \mathrm{H}), 7.61(\mathrm{~d}, J=8.5 \mathrm{~Hz}$, $1 \mathrm{H}), 7.56(\mathrm{ddd}, J=7.1,6.9,1.1 \mathrm{~Hz}, 1 \mathrm{H}), 7.01(\mathrm{~d}, J=15.9 \mathrm{~Hz}, 1 \mathrm{H}), 3.84(\mathrm{~s}, 3 \mathrm{H})$.

Methyl 3-(4-quinolynyl)-acrylate (6b)

Compounds $4 \mathbf{b}(785 \mathrm{mg}, 5 \mathrm{mmol})$ and $5(1.84 \mathrm{~g}, 5.5 \mathrm{mmol})$ were suspended in toluene $(15 \mathrm{~mL})$. The reaction mixture was refluxed for two hours until complete conversion occurred. After cooling to room temperature, the red solution was extracted with $1 \mathrm{~N}$ $\mathrm{HCl}(2 \times 20 \mathrm{~mL})$. The combined aqueous extracts were washed with EtOAc $(20 \mathrm{~mL})$ and neutralized with $10 \% \mathrm{NaOH}$. Extraction with EtOAc $(3 \times 20 \mathrm{~mL})$ afforded organic solution of the title product that was washed with brine $(20 \mathrm{~mL})$, dried over $\mathrm{Na}_{2} \mathrm{SO}_{4}$, and the solvent was evaporated. Thus, the red oil formed was passed through a plug of $\mathrm{SiO}_{2}(20 \mathrm{~g})$ and eluted with Hexanes:EtOAc (1:1). The title product was obtained as yellowish oil that slowly solidified $(930 \mathrm{mg}, 87 \%)$.

${ }^{1} \mathrm{H}-\mathrm{NMR}\left(500 \mathrm{MHz}, \mathrm{CDCl}_{3}\right) \delta: 9.21(\mathrm{~d}, J=4.5 \mathrm{~Hz}, 1 \mathrm{H}), 8.42(\mathrm{~d}, J=15.8 \mathrm{~Hz}, 1 \mathrm{H}), 8.17$ $(\mathrm{m}, 2 \mathrm{H}), 7.78(\mathrm{~m}, 1 \mathrm{H}), 7.64(\mathrm{ddd}, J=7.1,6.8,1.3 \mathrm{~Hz}, 1 \mathrm{H}), 7.55(\mathrm{~d}, J=4.5 \mathrm{~Hz}, 1 \mathrm{H}), 6.66(\mathrm{~d}$, $J=15.8 \mathrm{~Hz}, 1 \mathrm{H}), 3.87(\mathrm{~s}, 3 \mathrm{H})$.

3-(4-Quinolyl)-2-propene-1-ol (7b) [21]

A two-neck-round-bottom flask under argon was charged with compound $\mathbf{6 b}(610 \mathrm{mg}$, $2.86 \mathrm{mmol})$ and toluene $(15 \mathrm{~mL})$. The reaction mixture was cooled to $-78^{\circ} \mathrm{C}$, and DIBAL-H $(6.22 \mathrm{~mL}, 6.29 \mathrm{mmol})$ was added via syringe for a period of $10 \mathrm{~min}$. After $30 \mathrm{~min}$, conversion of the ester was complete. The reaction mixture was warmed to $0{ }^{\circ} \mathrm{C}$ and quenched with diethyl ether, water and $15 \%$ sodium hydroxide. It was stirred for $15 \mathrm{~min}$ at ambient temperature and $\mathrm{MgSO}_{4}$ was added. Inorganics were filtered off and washed with ether $(2 \times 20 \mathrm{~mL})$. Residue obtained after evaporation of the solvent was purified by SPE with mixtures of DCM 3\% methanolic ammonia. The title product was obtained as a off-white crystaline solid (290 mg, 51\%).

$\left.{ }^{1} \mathrm{H}-\mathrm{NMR}(500 \mathrm{MHz}, \mathrm{CDCl})_{3}\right) \delta: 8.67(\mathrm{~d}, J=4.6 \mathrm{~Hz}, 1 \mathrm{H}), 7.97(\mathrm{~d}, J=8.5 \mathrm{~Hz}, 1 \mathrm{H}), 7.94$ $(\mathrm{d}, J=8.5 \mathrm{~Hz}, 1 \mathrm{H}), 7.55(\mathrm{t}, J=7.2 \mathrm{~Hz}, 1 \mathrm{H}), 7.38(\mathrm{t}, J=7.3 \mathrm{~Hz}, 1 \mathrm{H}), 7.26(\mathrm{~d}, J=4.6 \mathrm{~Hz}, 1 \mathrm{H})$, $7.22(\mathrm{~d}, J=15.6 \mathrm{~Hz}, 1 \mathrm{H}), 6.45(\mathrm{dt}, J=15.6,4.9 \mathrm{~Hz}, 1 \mathrm{H}), 4.36(\mathrm{dd}, J=4.9,1.5 \mathrm{~Hz}, 2 \mathrm{H}), 3.11$ (brs., $1 \mathrm{H}) ;{ }^{13} \mathrm{C}-\mathrm{NMR}\left(126 \mathrm{MHz}, \mathrm{CDCl}_{3}\right) \delta: 149.9,148.3,143.0,136.2,129.7,129.4,126.5,126.2$, 124.4, 123.6, 117.5, 63.0.

\section{3-(2-Quinolinyl)-2-propene-1-ol (7a) [22].}

Compound was prepared analogously to $7 \mathbf{b}$, starting with $6 \mathbf{a}(770 \mathrm{mg}, 3.61 \mathrm{mmol})$. Crude product was purified by SPE on and eluted with mixtures of hexane and ethyl acetate. The product was obtained as a pale green solid $(160 \mathrm{mg}, 27 \%)$.

${ }^{1} \mathrm{H}-\mathrm{NMR}\left(300 \mathrm{MHz}, \mathrm{CDCl}_{3}\right) \delta: 8.07(\mathrm{~d}, J=8.4 \mathrm{~Hz}, 1 \mathrm{H}), 8.06(\mathrm{~d}, J=8.5 \mathrm{~Hz}, 1 \mathrm{H}), 7.75$ $(\mathrm{d}, J=8.2 \mathrm{~Hz}, 1 \mathrm{H}), 7.65-7.72(\mathrm{~m}, 1 \mathrm{H}), 7.43-7.56(\mathrm{~m}, 2 \mathrm{H}), 7.04(\mathrm{~d}, J=16.0 \mathrm{~Hz}, 1 \mathrm{H}), 6.91(\mathrm{dt}$, $J=16.0,4.5 \mathrm{~Hz}, 1 \mathrm{H}), 4.48(\mathrm{dd}, J=4.4,1.1 \mathrm{~Hz}, 2 \mathrm{H}) ;{ }^{13} \mathrm{C}-\mathrm{NMR}\left(75 \mathrm{MHz}, \mathrm{CDCl}_{3}\right) \delta: 155.1,147.0$, $135.9,135.8,129.5,129.1,128.2,126.8,126.6,125.5,118.3,62.0$. 
3-(4-Quinolyl)-allyl tert-butyl carbonate (8b).

Compound $7 \mathbf{b}(280 \mathrm{mg}, 1.51 \mathrm{mmol})$ was suspended in DCM $(5 \mathrm{~mL})$. Boc ${ }_{2} \mathrm{O}(0.42 \mathrm{~mL}$, $1.81 \mathrm{mmol})$ and DMAP $(18.47 \mathrm{mg}, 0.151 \mathrm{mmol})$ were added, and the reaction mixture Was stirred at ambient temperature for $1 \mathrm{~h}$. The reaction was quenched with sat $\mathrm{NaHCO}_{3}$ $(10 \mathrm{~mL})$ and stirred for $10 \mathrm{~min}$ more. Layers were separated, and the aqueous one was extracted with diethyl ether $(3 \times 10 \mathrm{~mL})$. Organics were dried over $\mathrm{Na}_{2} \mathrm{SO}_{4}$ and evaporated to dryness. Residue was purified by SPE and eluted with Hex:EtOAc. The title compound was obtained as colorless oil ( $340 \mathrm{mg}, 71 \%)$.

$\left.{ }^{1} \mathrm{H}-\mathrm{NMR}(500 \mathrm{MHz}, \mathrm{CDCl})_{3}\right) 8: 8.88(\mathrm{~d}, J=4.5 \mathrm{~Hz}, 1 \mathrm{H}), 8.08-8.12(\mathrm{~m} .2 \mathrm{H}), 7.70-7.75(\mathrm{~m}$, $1 \mathrm{H}), 7.55-7.59(\mathrm{~m}, 1 \mathrm{H}), 7.44(\mathrm{~d}, J=4.5 \mathrm{~Hz}, 1 \mathrm{H}), 7.38(\mathrm{dt}, J=15.8,1.3 \mathrm{~Hz}, 1 \mathrm{H}), 6.50(\mathrm{dt}, J=15.8$, $5.5 \mathrm{~Hz}, 1 \mathrm{H}), 4.91(\mathrm{dd}, J=5.5,1.3 \mathrm{~Hz}, 1 \mathrm{H}), 1.54(\mathrm{~s}, 9 \mathrm{H}) ;{ }^{13} \mathrm{C}-\mathrm{NMR}\left(101 \mathrm{MHz}, \mathrm{CDCl}_{3}\right) \delta: 153.2$, $150.2,148.5,142.1,130.1,130.0,129.4,128.3,126.6,126.1,123.5,117.8,82.6,66.8,27.8$ (3C).

\section{3-(2-Quinolyl)-allyl tert-butyl carbonate (8a).}

Compound 7a (150 mg, $0.810 \mathrm{mmol})$ was solved in DCM (5 mL). Boc $2 \mathrm{O}(0.226 \mathrm{~mL}$, $0.972 \mathrm{mmol})$ and DMAP $(9.89 \mathrm{mg}, 0.081 \mathrm{mmol})$ were added, and the reaction mixture was stirred at ambient temperature for $0.5 \mathrm{~h}$. The reaction was quenched with sat $\mathrm{NaHCO}_{3}$ $(10 \mathrm{~mL})$ and stirred for $10 \mathrm{~min}$ more. Layers were separated, and the aqueous one was extracted with diethyl ether $(3 \times 10 \mathrm{~mL})$. Organics were dried over $\mathrm{Na}_{2} \mathrm{SO}_{4}$ and evaporated to dryness. Residue was purified by SPE and eluted with Hex:EtOAc. The title compound was obtained as colorless oil (153 $\mathrm{mg}, 66 \%)$.

${ }^{1} \mathrm{H}-\mathrm{NMR}\left(400 \mathrm{MHz}, \mathrm{CDCl}_{3}\right) \delta: 8.08(\mathrm{~d}, J=8.5 \mathrm{~Hz}, 1 \mathrm{H}), 8.02(\mathrm{dd}, J=8.3,0.8 \mathrm{~Hz}, 1 \mathrm{H})$, $7.75(\mathrm{dd}, J=8.1,1.1 \mathrm{~Hz}, 1 \mathrm{H}), 7.67(\mathrm{~m}, 1 \mathrm{H}), 7.51(\mathrm{~d}, J=8.7 \mathrm{~Hz}, 1 \mathrm{H}), 7.47(\mathrm{dd}, J=6.9,1.2 \mathrm{~Hz}$, $1 \mathrm{H}), 6.95(\mathrm{dt}, J=16.1,1.3 \mathrm{~Hz}, 1 \mathrm{H}), 6.85(\mathrm{dt}, J=16.0,5.5 \mathrm{~Hz}, 1 \mathrm{H}), 4.83(\mathrm{dd}, J=5.6,1.3 \mathrm{~Hz}$, 2H), $1.50(\mathrm{~s}, 9 \mathrm{H}) ;{ }^{13} \mathrm{C}-\mathrm{NMR}\left(101 \mathrm{MHz}, \mathrm{CDCl}_{3}\right) \delta: 154.9,153.3,148.0,136.4,133.7,129.7,129.3$, $127.4,127.0,126.4,119.1,82.4,66.7,27.8(3 \mathrm{C})$.

Methyl 4-hydroxycrotonate (13a) [26]

Compounds 5 (6.68 g, $20 \mathrm{mmol})$ and $\mathbf{1 1}(1.2 \mathrm{~g}, 10 \mathrm{mmol})$ were suspended in chloroform $(60 \mathrm{~mL})$. The reaction mixture was stirred at ambient temperature for $24 \mathrm{~h}$. The solvent was removed under reduced pressure, and residue was subjected to bulb-to-bulb distillation $\left(150^{\circ} \mathrm{C} / 1.2 \times 10^{-1} \mathrm{mbarr}\right)$. The product was obtained as colorless oil $(2.1 \mathrm{~g}, 88 \%)$.

${ }^{1} \mathrm{H}-\mathrm{NMR}\left(400 \mathrm{MHz}, \mathrm{CDCl}_{3}\right)$ 8: $7.05(\mathrm{dt}, J=4.0,15.6 \mathrm{~Hz}, 1 \mathrm{H}), 6.15-6.08(\mathrm{~m}, 1 \mathrm{H}), 4.38-4.33$ $(\mathrm{m}, 2 \mathrm{H}), 3.74(\mathrm{~s}, 3 \mathrm{H})$.

4-Hydroxycrotononitrile (13b)

Compound was prepared the same way as 13a, starting with compounds $12(7.88 \mathrm{~g}$, $26.2 \mathrm{mmol})$ and $11(1.57 \mathrm{~g}, 13.08 \mathrm{mmol})$. The product was obtained as colorless oil (4:1 trans/cis mixture) after a bulb-to-bulb distillation $\left(120^{\circ} \mathrm{C} / 1.5 \times 10^{-1} \mathrm{mbarr}\right)$. Yield (1.94 g, $89 \%)$.

1. $\mathrm{H}$ NMR (500 MHz, $\left.\mathrm{CDCl}_{3}\right) \delta$ : (trans isomer) $6.84(\mathrm{dt}, \mathrm{J}=16.3,3.4 \mathrm{~Hz}, 1 \mathrm{H}), 5.73(\mathrm{dt}$, $\mathrm{J}=16.4,2.3 \mathrm{~Hz}, 1 \mathrm{H}), 4.33(\mathrm{t}, \mathrm{J}=2.9 \mathrm{~Hz}, 2 \mathrm{H})$; (cis isomer) $6.62(\mathrm{dt}, \mathrm{J}=11.4,5.8 \mathrm{~Hz}, 1 \mathrm{H}), 5.44$ $(\mathrm{dt}, \mathrm{J}=11.3,1.7 \mathrm{~Hz}, 1 \mathrm{H}), 4.47(\mathrm{dd}, \mathrm{J}=5.8,1.5 \mathrm{~Hz}, 2 \mathrm{H}) ;{ }^{13} \mathrm{C}-\mathrm{NMR}\left(126 \mathrm{MHz}, \mathrm{CDCl}_{3}\right) \delta$ : (trans isomer) 153.6, 117.3, 98.4, 61.5; (cis isomer) 152.9, 117.3, 99.4, 61.2.

Methyl-4-tert-butyloxycarbonyloxy-crotonate (14a)

Compound 13a $(6.1 \mathrm{~g}, 52.5 \mathrm{mmol})$ was solved in DCM $(70 \mathrm{~mL}) . \mathrm{Boc}_{2} \mathrm{O}(14.64 \mathrm{~mL}$, $63.0 \mathrm{mmol})$ was added, followed by DMAP $(0.321 \mathrm{~g}, 2.63 \mathrm{mmol})$. The reaction mixture was stirred for $2 \mathrm{~h}$ at room temperature and then washed with $1 \mathrm{~N} \mathrm{HCl}(2 \times 50 \mathrm{~mL})$, water $(50 \mathrm{~mL})$, and brine $(50 \mathrm{~mL})$. Organic layer was dried over $\mathrm{Na}_{2} \mathrm{SO}_{4}$, and the solvent removed under reduced pressure. The red-brown oily residue was passed through a plug of $\mathrm{SiO}_{2}$ $(30 \mathrm{~g})$ and eluted with EtOAc:Hex (1:2). The title product was obtained as yellow oil (10 g, 88\%). 
${ }^{1} \mathrm{H}-\mathrm{NMR}\left(600 \mathrm{MHz}, \mathrm{CDCl}_{3}\right) \delta: 6.90(\mathrm{td}, J=15.7,4.7 \mathrm{~Hz}, 1 \mathrm{H}), 6.02(\mathrm{dt}, J=15.9,1.9 \mathrm{~Hz}$, $1 \mathrm{H}), 4.68(\mathrm{dd}, J=4.6,2.0 \mathrm{~Hz}, 2 \mathrm{H}), 3.70(\mathrm{~s}, 3 \mathrm{H}), 1.45(\mathrm{~s}, 9 \mathrm{H}) ;{ }^{13} \mathrm{C}-\mathrm{NMR}\left(151 \mathrm{MHz}, \mathrm{CDCl}_{3}\right) \delta$ : $166.2,152.9,141.3,121.8,82.7,64.8,51.7,27.7$.

4-tert-Butyloxycarbonyloxy-crotononitrile (14b)

Compound was prepared in a similar way to $\mathbf{1 4 a}$ starting from compound $\mathbf{1 3 b}$ (1.32 $\mathrm{g}$, $15.9 \mathrm{mmol})$. The title product was obtained as a yellowish oily mixture of trans/cis iso$\operatorname{mers}(4: 1)(2.4 \mathrm{~g}, 78 \%)$.

${ }^{1} \mathrm{H}-\mathrm{NMR}\left(300 \mathrm{MHz}, \mathrm{CDCl}_{3}\right) \delta$ : (trans isomer) $6.68(\mathrm{dt}, J=16.4,4.4 \mathrm{~Hz}, 1 \mathrm{H}), 5.59(\mathrm{dt}$, $J=16.3,2.2 \mathrm{~Hz}, 1 \mathrm{H}), 4.65(\mathrm{dd}, J=4.4,2.1 \mathrm{~Hz}, 2 \mathrm{H}), 1.44(\mathrm{~s}, 9 \mathrm{H})$; (cis isomer) $6.54(\mathrm{dt}, J=11.2$, $6.2 \mathrm{~Hz}, 1 \mathrm{H}), 5.50(\mathrm{dt}, J=11.2,1.7 \mathrm{~Hz}, 1 \mathrm{H}), 4.84(\mathrm{dd}, J=6.1,1.7 \mathrm{~Hz}, 2 \mathrm{H}), 1.47(\mathrm{~s}, 9 \mathrm{H}) ;{ }^{13} \mathrm{C}-\mathrm{NMR}$ $\left(75 \mathrm{MHz}, \mathrm{CDCl}_{3}\right) \delta$ : (trans isomer) 152.5, 147.5, 116.5, 101.1, 83.3, 64.5, 27.6 (3C).

(22R)-9-Deoxo-11-deoxy-11-9a-(epoxyethano)-22-(2-quinolyl)methyl-9a-aza-9a- homoerythromycin A (10a)

A flame dried Schlenk tube was charged under argon with compounds 1 (184 mg, $0.25 \mathrm{mmol}), 8 \mathbf{a}(85 \mathrm{mg}, 0.27 \mathrm{mmol})$ and dry toluene $(2.5 \mathrm{~mL}) . \mathrm{Pd}_{2}(\mathrm{dba})_{3} \cdot \mathrm{CHCl}_{3}(6 \mathrm{mg}$, $0.005 \mathrm{mmol})$ and DPPB (5 mg, $0.01 \mathrm{mmol})$ were added, and the reaction mixture was heated at $80{ }^{\circ} \mathrm{C}$ for $1 \mathrm{~h}$. After completion of the reaction, DBU (152 mg, $\left.1 \mathrm{mmol}\right)$ was added, and the reaction mixture was heated for another $1 \mathrm{~h}$. The solvent was evaporated under reduced pressure, and foamy residue was chromatographed on $\mathrm{SiO}_{2}(20 \mathrm{~g})$ EtOAc:Hexanes:DEA (100:100:10) and further on the same amount of silica with DCM:MeOH: $\mathrm{NH}_{4} \mathrm{OH}(90: 6: 0.5)$. The title product was obtained as a white solid $(80 \mathrm{mg}, 35 \%)$.

${ }^{1} \mathrm{H}-\mathrm{NMR}\left(500 \mathrm{MHz}, \mathrm{CDCl}_{3}\right) \delta: 8.12(\mathrm{~d}, J=8.5 \mathrm{~Hz}, 1 \mathrm{H}), 8.04(\mathrm{~d}, J=8.5 \mathrm{~Hz}, 1 \mathrm{H}), 7.78$ $(\mathrm{dd}, J=8.4,1.1 \mathrm{~Hz}, 1 \mathrm{H}), 7.75(\mathrm{~d}, J=8.5 \mathrm{~Hz}, 1 \mathrm{H}), 7.63-7.71(\mathrm{~m}, 1 \mathrm{H}), 7.49(\mathrm{ddd}, J=8.0,6.9$, $1.2 \mathrm{~Hz}, 1 \mathrm{H}), 5.94(\mathrm{~s}, 1 \mathrm{H}), 4.97(\mathrm{dd}, J=4.6,1.5 \mathrm{~Hz}, 1 \mathrm{H}), 4.67(\mathrm{dd}, J=11.3,2.1 \mathrm{~Hz}, 1 \mathrm{H}), 4.48(\mathrm{~d}$, $J=7.3 \mathrm{~Hz}, 1 \mathrm{H}), 4.28-4.36(\mathrm{~m}, 1 \mathrm{H}), 4.25(\mathrm{dd}, J=8.5,1.8 \mathrm{~Hz}, 1 \mathrm{H}), 4.09(\mathrm{dq}, J=8.7,6.3 \mathrm{~Hz}, 1 \mathrm{H})$, $3.77(\mathrm{~d}, J=6.7 \mathrm{~Hz}, 1 \mathrm{H}), 3.51-3.60(\mathrm{~m}, 1 \mathrm{H}), 3.35(\mathrm{~d}, J=1.8 \mathrm{~Hz}, 1 \mathrm{H}), 3.32(\mathrm{~s}, 3 \mathrm{H}), 3.30-3.34(\mathrm{~m}$, $1 \mathrm{H}), 3.27(\mathrm{dd}, J=15.0,4.9 \mathrm{~Hz}, 1 \mathrm{H}), 3.22(\mathrm{dd}, J=15.0,8.2 \mathrm{~Hz}, 1 \mathrm{H}), 3.07(\mathrm{~d}, J=8.5 \mathrm{~Hz}, 1 \mathrm{H})$, 2.87-2.94 (m, 1H), 2.59-2.71 (m, 3H), $2.54(\mathrm{t}, J=11.0 \mathrm{~Hz}, 1 \mathrm{H}), 2.44(\mathrm{~s}, 6 \mathrm{H}), 2.34(\mathrm{dd}, J=15.0$, $1.8 \mathrm{~Hz}, 1 \mathrm{H}), 2.29(\mathrm{dd}, J=12.7,3.2 \mathrm{~Hz}, 1 \mathrm{H}), 1.93-2.04(\mathrm{~m}, 2 \mathrm{H}), 1.82-1.90(\mathrm{~m}, 3 \mathrm{H}), 1.72(\mathrm{dd}$, $J=14.6,1.8 \mathrm{~Hz}, 1 \mathrm{H}), 1.65-1.70(\mathrm{~m}, 1 \mathrm{H}), 1.63(\mathrm{dd}, J=15.0,4.9 \mathrm{~Hz}, 1 \mathrm{H}), 1.36-1.45(\mathrm{~m}, 2 \mathrm{H})$, $1.35(\mathrm{~d}, J=6.4 \mathrm{~Hz}, 3 \mathrm{H}), 1.33(\mathrm{~s}, 3 \mathrm{H}), 1.28-1.32(\mathrm{~m}, 1 \mathrm{H}), 1.26(\mathrm{~s}, 3 \mathrm{H}), 1.25(\mathrm{~d}, J=7.3 \mathrm{~Hz}, 3 \mathrm{H})$, $1.24(\mathrm{~d}, J=6.1 \mathrm{~Hz}, 3 \mathrm{H}), 1.07(\mathrm{~d}, J=7.6 \mathrm{~Hz}, 3 \mathrm{H}), 1.01(\mathrm{~s}, 3 \mathrm{H}), 0.93(\mathrm{~d}, J=6.4 \mathrm{~Hz}, 3 \mathrm{H}), 0.91(\mathrm{~d}$, $J=7.0 \mathrm{~Hz}, 3 \mathrm{H}), 0.70(\mathrm{t}, J=7.5 \mathrm{~Hz}, 3 \mathrm{H}) ;{ }^{13} \mathrm{C}-\mathrm{NMR}\left(75 \mathrm{MHz}, \mathrm{CDCl}_{3}\right) \delta: 175.9(\mathrm{C}), 158.7(\mathrm{C})$, $147.6(\mathrm{C}), 136.1(\mathrm{CH}), 129.2(\mathrm{CH}), 128.7(\mathrm{CH}), 127.5(\mathrm{CH}), 127.0(\mathrm{C}), 125.8(\mathrm{CH}), 122.1(\mathrm{CH})$, $103.1(\mathrm{CH}), 96.5(\mathrm{CH}), 84.9(\mathrm{CH}), 80.6(\mathrm{CH}), 78.9(\mathrm{CH}), 77.8(\mathrm{CH}), 77.4(\mathrm{CH}), 74.1(\mathrm{CH}), 73.9$ (C), $73.1(\mathrm{C}), 72.9(\mathrm{C}), 71.1(\mathrm{CH}), 68.6(\mathrm{CH}), 66.2(\mathrm{CH}), 65.6(\mathrm{CH}), 64.1\left(\mathrm{CH}_{2}\right), 56.6(\mathrm{CH}), 49.4$ $\left(\mathrm{CH}_{2}\right), 49.4\left(\mathrm{CH}_{3}\right), 44.8(\mathrm{CH}), 42.7\left(\mathrm{CH}_{2}\right), 41.5\left(\mathrm{CH}_{2}\right), 40.4\left(2 \mathrm{CCH}_{3}\right), 39.6\left(\mathrm{CH}_{3}\right), 35.3\left(\mathrm{CH}_{2}\right)$, $29.6\left(\mathrm{CH}_{2}\right), 26.6\left(\mathrm{C} \& \mathrm{CH}_{3}\right), 21.6\left(\mathrm{CH}_{3}\right), 21.3\left(\mathrm{CH}_{3}\right), 21.3\left(\mathrm{CH}_{3}\right), 20.2\left(\mathrm{CH}_{2}\right), 18.6\left(\mathrm{CH}_{3}\right), 16.5$ $\left(\mathrm{CH}_{3}\right), 15.3\left(\mathrm{CH}_{3}\right), 10.7\left(\mathrm{CH}_{3}\right), 9.6\left(\mathrm{CH}_{3}\right), 5.4\left(\mathrm{CH}_{3}\right)$; HRMS (ES $\left.{ }^{+}\right)$Calc. for $\mathrm{C}_{49} \mathrm{H}_{80} \mathrm{~N}_{3} \mathrm{O}_{12}$ $\left([\mathrm{M}+\mathrm{H}]^{+}\right)$: 902.5742; found: 902.5740 .

(22R)-9-Deoxo-11-deoxy-11-9a-(epoxyethano)-22-(4-quinolyl)methyl-9a-aza-9a- homoerythromycin A (10b)

A flame dried Schlenk tube was charged under argon with compounds 1 (184 mg, $0.25 \mathrm{mmol}), 8 \mathbf{b}(77 \mathrm{mg}, 0.27 \mathrm{mmol})$, and dry toluene $(3 \mathrm{~mL}) . \mathrm{Pd}_{2}(\mathrm{dba})_{3} \cdot \mathrm{CHCl}_{3}(6 \mathrm{mg}$, $0.005 \mathrm{mmol})$ and DPPB ( $5 \mathrm{mg}, 0.01 \mathrm{mmol})$ were added, and the reaction mixture was heated at $80{ }^{\circ} \mathrm{C}$ for $1 \mathrm{~h}$. After completion of the reaction, DBU (152 mg, $\left.1 \mathrm{mmol}\right)$ was added, and the reaction mixture was heated for another $1 \mathrm{~h}$. The solvent was evaporated under reduced pressure, and foamy residue was chromatographed on $\mathrm{SiO}_{2}(20 \mathrm{~g})$ EtOAc:Hexanes:DEA (100:100:10) and further on the same amount of silica with DCM:MeOH: $\mathrm{NH}_{4} \mathrm{OH}(90: 6: 0.5)$. The title product was obtained as a white solid (103 $\mathrm{mg}, 46 \%)$.

${ }^{1} \mathrm{H}-\mathrm{NMR}\left(500 \mathrm{MHz}, \mathrm{CDCl}_{3}\right) \delta: 8.84(\mathrm{~d}, J=4.3 \mathrm{~Hz}, 1 \mathrm{H}), 8.11(\mathrm{~d}, J=7.9 \mathrm{~Hz}, 1 \mathrm{H}), 8.06(\mathrm{~d}$, $J=8.1 \mathrm{~Hz}, 1 \mathrm{H}), 7.68(\mathrm{~m}, 2 \mathrm{H}), 7.55(\mathrm{ddd}, J=7.9,7.0,1.1 \mathrm{~Hz}, 1 \mathrm{H}), 6.58(\mathrm{~s}, 1 \mathrm{H}), 4.94(\mathrm{dd}, J=4.4$, 
$2.5 \mathrm{~Hz}, 1 \mathrm{H}), 4.60(\mathrm{dd}, J=11.1,2.2 \mathrm{~Hz}, 1 \mathrm{H}), 4.51(\mathrm{~d}, J=7.2 \mathrm{~Hz}, 1 \mathrm{H}), 4.27(\mathrm{~m}, 1 \mathrm{H}), 4.17(\mathrm{dd}$, $J=9.0,1.6 \mathrm{~Hz}, 1 \mathrm{H}), 4.06(\mathrm{dq}, J=8.2,6.4 \mathrm{~Hz}, 1 \mathrm{H}), 3.78(\mathrm{~d}, J=6.6 \mathrm{~Hz}, 1 \mathrm{H}), 3.58(\mathrm{~m}, 1 \mathrm{H}), 3.37$ $(\mathrm{dd}, J=9.8,7.6 \mathrm{~Hz}, 1 \mathrm{H}), 3.34(\mathrm{~d}, J=1.8 \mathrm{~Hz}, 1 \mathrm{H}), 3.31(\mathrm{~s}, 3 \mathrm{H}), 3.30(\mathrm{~d}, J=13.7 \mathrm{~Hz}, 1 \mathrm{H}), 3.23$ $(\mathrm{dd}, J=14.5, \mathrm{~Hz}, 1 \mathrm{H}), 3.09(\mathrm{~d}, J=8.1 \mathrm{~Hz}, 1 \mathrm{H}), 2.90(\mathrm{dq}, J=8.9,7.2 \mathrm{~Hz}, 1 \mathrm{H}), 2.87(\mathrm{~m}, 1 \mathrm{H})$, $2.65(\mathrm{~s}, 6 \mathrm{H}), 2.64(\mathrm{~m}, 2 \mathrm{H}), 2.52(\mathrm{~d}, J=11.3 \mathrm{~Hz}, 1 \mathrm{H}), 2.41(\mathrm{~m}, 1 \mathrm{H}), 2.30(\mathrm{dd}, J=14.7,2.3 \mathrm{~Hz}$, $1 \mathrm{H}), 2.29(\mathrm{dd}, J=12.7,3.3 \mathrm{~Hz}, 1 \mathrm{H}), 2.24(\mathrm{~s}, 1 \mathrm{H}), 2.02(\mathrm{~m}, 3 \mathrm{H}), 1.89(\mathrm{~m}, 1 \mathrm{H}), 1.68(\mathrm{dd}, J=14.7$, $1.2 \mathrm{~Hz}, 1 \mathrm{H}), 1.64(\mathrm{dd}, J=14.9,4.6 \mathrm{~Hz}, 1 \mathrm{H}), 1.62(\mathrm{~m}, 1 \mathrm{H}), 1.37(\mathrm{~m}, 3 \mathrm{H}), 1.34(\mathrm{~d}, J=7.0 \mathrm{~Hz}, 3 \mathrm{H})$, $1.31(\mathrm{~s}, 3 \mathrm{H}), 1.25(\mathrm{~d}, J=6.8 \mathrm{~Hz}, 6 \mathrm{H}), 1.27(\mathrm{~s}, 3 \mathrm{H}), 1.04(\mathrm{~d}, J=7.5 \mathrm{~Hz}, 3 \mathrm{H}), 0.98(\mathrm{~s}, 3 \mathrm{H}), 0.92$ $(\mathrm{d}, J=7.0 \mathrm{~Hz}, 3 \mathrm{H}), 0.75(\mathrm{t}, J=7.4 \mathrm{~Hz}, 3 \mathrm{H}){ }^{13} \mathrm{C}-\mathrm{NMR}\left(75.47 \mathrm{MHz}, \mathrm{CDCl}_{3}\right) \delta: 174.5(\mathrm{C}), 149.2$ $(\mathrm{CH}), 147.0(\mathrm{C}), 142.5(\mathrm{C}), 129.2(\mathrm{CH}), 127.8(\mathrm{CH}), 127.5(\mathrm{C}), 125.1(\mathrm{CH}), 122.7(\mathrm{CH}), 120.8$ (CH), 101.9 (CH), $95.7(\mathrm{CH}), 84.7(\mathrm{CH}), 80.1(\mathrm{CH}), 77.9(\mathrm{CH}), 76.4(\mathrm{CH}), 76.2(\mathrm{CH}), 72.9(\mathrm{CH})$, $72.7(\mathrm{C}), 72.0(\mathrm{C}), 72.0(\mathrm{C}), 70.0(\mathrm{CH}), 67.2(\mathrm{CH}), 65.7(\mathrm{CH}), 64.7(\mathrm{CH}), 63.0\left(\mathrm{CH}_{2}\right), 55.5(\mathrm{CH})$, $48.4\left(\mathrm{CH}_{2}\right), 48.3\left(\mathrm{CH}_{3}\right), 43.5(\mathrm{CH}), 40.3\left(\mathrm{CH}_{2}\right), 39.6\left(2 \mathrm{xCH}_{3}\right), 37.8(\mathrm{CH}), 34.4\left(\mathrm{CH}_{2}\right), 33.7$ $\left(\mathrm{CH}_{2}\right)$, 30.3, $\left(\mathrm{CH}_{2}\right), 25.6(\mathrm{CH}), 25.4\left(\mathrm{CH}_{3}\right), 20.5\left(\mathrm{CH}_{3}\right), 20.3\left(\mathrm{CH}_{3}\right), 20.1\left(\mathrm{CH}_{3}\right), 19.1\left(\mathrm{CH}_{2}\right)$, $17.5\left(\mathrm{CH}_{3}\right), 15.6\left(\mathrm{CH}_{3}\right), 14.1\left(\mathrm{CH}_{3}\right), 9.7\left(\mathrm{CH}_{3}\right), 8.7\left(\mathrm{CH}_{3}\right), 4.1\left(\mathrm{CH}_{3}\right)$; HRMS $\left(\mathrm{ES}^{+}\right)$Calc. for $\mathrm{C}_{49} \mathrm{H}_{80} \mathrm{~N}_{3} \mathrm{O}_{12}\left([\mathrm{M}+\mathrm{H}]^{+}\right)$: 902.5742; found: 902.5753 .

(22R)-9-Deoxo-11-deoxy-11-9a-(epoxyethano)-22-(methoxycarbonyl)methyl-9a-aza-9a- homoerythromycin A (15a)

According to the procedure above, starting with compounds 1 (367 mg, $0.5 \mathrm{mmol})$ and 14a (130 mg, $0.6 \mathrm{mmol})$. Yield (170 mg, 41\%).

${ }^{1} \mathrm{H}-\mathrm{NMR}\left(500 \mathrm{MHz}, \mathrm{CDCl}_{3}\right) \delta: 5.61(\mathrm{~s}, 1 \mathrm{H}), 4.95(\mathrm{~d}, J=4.3 \mathrm{~Hz}, 1 \mathrm{H}), 4.88 \mathrm{dd}, J=11.3$, $1.8 \mathrm{~Hz}, 1 \mathrm{H}), 4.43(\mathrm{~d}, J=7.0 \mathrm{~Hz}, 1 \mathrm{H}), 4.23(\mathrm{dd}, J=8.8,1.8 \mathrm{~Hz}, 1 \mathrm{H}), 3.98-4.14(\mathrm{~m}, 2 \mathrm{H}), 3.75$ $(\mathrm{d}, J=6.7 \mathrm{~Hz}, 1 \mathrm{H}), 3.70(\mathrm{~s}, 3 \mathrm{H}), 3.45-3.57(\mathrm{~m}, 1 \mathrm{H}), 3.35(\mathrm{~d}, J=1.8 \mathrm{~Hz}, 1 \mathrm{H}), 3.31(\mathrm{~s}, 3 \mathrm{H})$, $3.23(\mathrm{dd}, J=10.1,7.3 \mathrm{~Hz}, 1 \mathrm{H}), 3.03(\mathrm{t}, J=8.5 \mathrm{~Hz}, 1 \mathrm{H}), 2.88-2.97(\mathrm{~m}, 1 \mathrm{H}), 2.67(\mathrm{qd}, J=6.4$, $1.2 \mathrm{~Hz}, 1 \mathrm{H}), 2.60(\mathrm{dd}, J=15.0,2.8 \mathrm{~Hz}, 1 \mathrm{H}), 2.59(\mathrm{dd}, J=14.6,5.2 \mathrm{~Hz}, 1 \mathrm{H}), 2.53(\mathrm{~d}, J=11.3 \mathrm{~Hz}$, $1 \mathrm{H}), 2.48(\mathrm{dd}, J=14.8,6.9 \mathrm{~Hz}, 1 \mathrm{H}), 2.41-2.46(\mathrm{~m}, 1 \mathrm{H}), 2.36(\mathrm{~d}, J=15.0 \mathrm{~Hz}, 1 \mathrm{H}), 2.29(\mathrm{~s}, 6 \mathrm{H})$, 2.24-2.27 (m, 2H), 1.97-2.03 (m, 1H), 1.92-1.97 (m, 1H), 1.80-1.92 (m, 2H), $1.76(\mathrm{dd}, J=14.6$, $1.5 \mathrm{~Hz}, 1 \mathrm{H}), 1.63-1.69(\mathrm{~m}, 1 \mathrm{H}), 1.60(\mathrm{dd}, J=15.0,4.9 \mathrm{~Hz}, 1 \mathrm{H}), 1.44-1.49(\mathrm{~m}, 1 \mathrm{H}), 1.41(\mathrm{dd}$, $J=14.8,4.7 \mathrm{~Hz}, 1 \mathrm{H}), 1.33(\mathrm{~s}, 3 \mathrm{H}), 1.32(\mathrm{~d}, J=6.6 \mathrm{~Hz}, 3 \mathrm{H}), 1.26-1.31(\mathrm{~m}, 1 \mathrm{H}), 1.24(\mathrm{~s}, 3 \mathrm{H})$, $1.23(\mathrm{~d}, J=6.0 \mathrm{~Hz}, 3 \mathrm{H}), 1.23(\mathrm{~d}, J=6.1 \mathrm{~Hz}, 3 \mathrm{H}), 1.09(\mathrm{~d}, J=7.6 \mathrm{~Hz}, 3 \mathrm{H}), 1.04(\mathrm{~s}, 3 \mathrm{H}), 1.00(\mathrm{~d}$, $J=6.4 \mathrm{~Hz}, 3 \mathrm{H}), 0.92(\mathrm{~d}, J=7.0 \mathrm{~Hz}, 3 \mathrm{H}), 0.85(\mathrm{t}, J=7.9 \mathrm{~Hz}, 3 \mathrm{H}) ;{ }^{13} \mathrm{C}-\mathrm{NMR}\left(126 \mathrm{MHz}, \mathrm{CDCl}_{3}\right)$ ठ: $175.8(\mathrm{C}), 170.9(\mathrm{C}), 103.4(\mathrm{CH}), 96.7(\mathrm{CH}), 84.7(\mathrm{CH}), 80.7(\mathrm{CH}), 79.0(\mathrm{CH}), 78.2(\mathrm{CH}), 77.1$ $(\mathrm{CH}), 74.0(\mathrm{C}), 73.2(\mathrm{C}), 72.9(\mathrm{C}), 72.4(\mathrm{CH}), 71.2(\mathrm{CH}), 68.8(\mathrm{CH}), 65.9(\mathrm{CH}), 65.7(\mathrm{CH}), 64.1$ $(\mathrm{CH}), 56.5(\mathrm{CH}), 51.7\left(\mathrm{CH}_{3}\right), 49.5\left(\mathrm{CH}_{3}\right), 48.9\left(\mathrm{CH}_{2}\right), 44.8(\mathrm{CH}), 41.7\left(\mathrm{CH}_{2}\right), 40.5\left(2 \mathrm{CCH}_{3}\right)$, 39.7 $(\mathrm{CH}), 38.7\left(\mathrm{CH}_{2}\right), 35.4\left(\mathrm{CH}_{2}\right), 29.0\left(\mathrm{CH}_{2}\right), 26.8(\mathrm{CH}), 26.7\left(\mathrm{CH}_{3}\right), 21.6\left(\mathrm{CH}_{3}\right), 21.5\left(\mathrm{CH}_{3}\right)$, $21.4\left(\mathrm{CH}_{3}\right), 20.4\left(\mathrm{CH}_{2}\right), 18.7\left(\mathrm{CH}_{3}\right), 16.7\left(\mathrm{CH}_{3}\right), 15.3\left(\mathrm{CH}_{3}\right), 10.8\left(\mathrm{CH}_{3}\right), 9.7\left(\mathrm{CH}_{3}\right), 5.5\left(\mathrm{CH}_{3}\right)$; HRMS (ES ${ }^{+}$) Calc. for $\mathrm{C}_{42} \mathrm{H}_{77} \mathrm{~N}_{2} \mathrm{O}_{14}\left([\mathrm{M}+\mathrm{H}]^{+}\right)$: 833.53; found: 833.5382 .

(22R)-9-Deoxo-11-deoxy-11-9a-(epoxyethano)-22-(cyano)methyl-9a-aza-9a-homoerythromycin A (15a)

According to the procedure above, starting with compounds $\mathbf{1}(735 \mathrm{mg}, 1 \mathrm{mmol}, \mathbf{1 4 b}$ (217 mg, $1.18 \mathrm{mmol})$, yield was $621 \mathrm{mg}(69 \%)$.

${ }^{1} \mathrm{H}-\mathrm{NMR}\left(500 \mathrm{MHz}, \mathrm{CDCl}_{3}\right) \delta: 5.54(\mathrm{~s}, 1 \mathrm{H}), 4.90-4.98(\mathrm{~m}, 2 \mathrm{H}), 4.41(\mathrm{~d}, J=7.3 \mathrm{~Hz}$, $1 \mathrm{H}), 4.19(\mathrm{dd}, J=8.7,1.4 \mathrm{~Hz}, 1 \mathrm{H}), 4.06(\mathrm{dq}, J=9.2,6.2 \mathrm{~Hz}, 1 \mathrm{H}), 3.90-4.00(\mathrm{~m}, 1 \mathrm{H}), 3.74(\mathrm{~d}$, $J=7.6 \mathrm{~Hz}, 1 \mathrm{H}), 3.46-3.56(\mathrm{~m}, 1 \mathrm{H}), 3.40(\mathrm{~d}, J=1.53 \mathrm{~Hz}, 1 \mathrm{H}), 3.31(\mathrm{~s}, 3 \mathrm{H}), 3.23(\mathrm{dd}, J=10.1$, $7.3 \mathrm{~Hz}, 1 \mathrm{H}), 3.03(\mathrm{~d}, J=9.2 \mathrm{~Hz}, 1 \mathrm{H}), 2.89-2.99(\mathrm{~m}, 1 \mathrm{H}), 2.79$ (dd, $J=17.1,4.9 \mathrm{~Hz}, 1 \mathrm{H})$, 2.70-2.74 (m, 1H), 2.65-2.70 (m, 1H), $2.60(\mathrm{dd}, J=11.6,3.1 \mathrm{~Hz}, 1 \mathrm{H}), 2.51(\mathrm{dd}, J=17.1,4.0 \mathrm{~Hz}$, $1 \mathrm{H}), 2.41-2.48(\mathrm{~m}, 1 \mathrm{H}), 2.36(\mathrm{~d}, J=15.5 \mathrm{~Hz}, 1 \mathrm{H}), 2.31-2.33(\mathrm{~m}, 1 \mathrm{H}), 2.29(\mathrm{~s}, 6 \mathrm{H}), 2.03(\mathrm{t}$, $J=12.2 \mathrm{~Hz}, 1 \mathrm{H}), 1.82-1.96(\mathrm{~m}, 3 \mathrm{H}), 1.77(\mathrm{~d}, J=15.0 \mathrm{~Hz}, 1 \mathrm{H}), 1.63-1.70(\mathrm{~m}, 1 \mathrm{H}), 1.60(\mathrm{dd}$, $J=15.3,4.9 \mathrm{~Hz}, 1 \mathrm{H}), 1.46-1.55(\mathrm{~m}, 1 \mathrm{H}), 1.42(\mathrm{dd}, J=15.0,4.9 \mathrm{~Hz}, 1 \mathrm{H}), 1.34(\mathrm{~s}, 3 \mathrm{H}), 1.32(\mathrm{~d}$, $J=6.1 \mathrm{~Hz}, 3 \mathrm{H}), 1.26-1.31(\mathrm{~m}, 1 \mathrm{H}), 1.24(\mathrm{~s}, 3 \mathrm{H}), 1.23(\mathrm{~d}, J=6.4 \mathrm{~Hz}, 3 \mathrm{H}), 1.23(\mathrm{~d}, J=6.1 \mathrm{~Hz}$, $3 \mathrm{H}), 1.10(\mathrm{~d}, J=7.3 \mathrm{~Hz}, 3 \mathrm{H}), 1.07(\mathrm{~d}, J=7.0 \mathrm{~Hz}, 3 \mathrm{H}), 1.06(\mathrm{~s}, 3 \mathrm{H}), 0.93(\mathrm{~d}, J=7.0 \mathrm{~Hz}, 3 \mathrm{H}), 0.88$ $(\mathrm{t}, J=7.3 \mathrm{~Hz}, 3 \mathrm{H}) ;{ }^{13} \mathrm{C}-\mathrm{NMR}\left(126 \mathrm{MHz}, \mathrm{CDCl}_{3}\right) \delta: 176.1(\mathrm{C}), 116.5(\mathrm{C}), 103.4(\mathrm{CH}), 96.8(\mathrm{CH})$, $84.4(\mathrm{CH}), 80.7(\mathrm{CH}), 79.3(\mathrm{CH}), 78.1(\mathrm{CH}), 77.1(\mathrm{CH}), 74.1(\mathrm{C}), 73.2(\mathrm{C}), 72.8(\mathrm{C}), 71.1(\mathrm{CH})$, 
$70.1(\mathrm{CH}), 68.8(\mathrm{CH}), 65.8(\mathrm{CH}), 65.6(\mathrm{CH}), 64.0\left(\mathrm{CH}_{2}\right), 56.4(\mathrm{CH}), 49.4\left(\mathrm{CH}_{3}\right), 48.1\left(\mathrm{CH}_{2}\right)$, $44.8(\mathrm{CH}), 41.7\left(\mathrm{CH}_{2}\right), 40.4\left(2 \times \mathrm{CH}_{3}\right), 39.7(\mathrm{CH}), 35.4\left(\mathrm{CH}_{2}\right), 28.9\left(\mathrm{CH}_{2}\right), 26.7(\mathrm{CH}), 26.7$ $\left(\mathrm{CH}_{3}\right), 22.3\left(\mathrm{CH}_{2}\right), 21.6\left(\mathrm{CH}_{3}\right), 21.4\left(\mathrm{CH}_{3}\right), 21.3\left(\mathrm{CH}_{3}\right), 20.3\left(\mathrm{CH}_{2}\right), 18.7\left(\mathrm{CH}_{3}\right), 16.7\left(\mathrm{CH}_{3}\right)$, $15.3\left(\mathrm{CH}_{3}\right), 10.7\left(\mathrm{CH}_{3}\right), 9.6\left(\mathrm{CH}_{3}\right), 5.7\left(\mathrm{CH}_{3}\right)$; HRMS $\left(\mathrm{ES}^{+}\right)$Calc. for $\mathrm{C}_{41} \mathrm{H}_{74} \mathrm{~N}_{3} \mathrm{O}_{12}\left([\mathrm{M}+\mathrm{H}]^{+}\right)$: 800.5273 ; found: 800.5266 .

\section{Conclusions}

In conclusion, a tandem one-pot palladium catalyzed allylic alkylation/intermolecular Michael addition procedure was developed. It allowed preparation of a series of bicyclic azalides that contained a condensed, highly substituted morpholine ring created by bridging of azalide $\mathrm{N}-9 \mathrm{a}$ and $11-\mathrm{OH}$ group via tandem diallylation. This modification, although positioned in the western part of the macrocycle, affected the conformation of the whole molecule, causing the outward folding of the C-3 to C-5 region into a so-called "folded-out" conformation. Although a similar reaction with similar resulting compound was reported earlier [19], stereoselectivity of our procedure is unprecedented, yielding only one stereoisomer in all obtained products. Although compounds containing heteroaryl substituents seem to be potent growth inhibitors of erythromycin sensitive strains, they still have low activity against resistant strains. Therefore, we suggest employing them as the starting points for further transformations and optimizations.

Supplementary Materials: The following supporting information can be downloaded.

Author Contributions: S.A. and I.J.E. did the synthetic experimental work, A.Č. performed the NMR analyses, H.Č.P. performed the biological activity experiments. All authors have read and agreed to the published version of the manuscript.

Funding: This research received no external funding.

Data Availability Statement: The data presented in this study are available in experimental section of the article or in supplementary materials.

Acknowledgments: We are very thankful to Bill Leavens from Analytical Chemistry Department, MDR, GSK Medicines Research Center, Stevenage for HRMS measurements.

Conflicts of Interest: The authors declare no conflict of interest.

\section{References}

1. Pal, S. A journey across the sequential development of macrolides and ketolides related to erythromycin. Tetrahedron 2006, 62, 3171-3200. [CrossRef]

2. Ma, X.; Ma, S. Significant breakthroughs in search for anti-infectious agents derived from erythromycin A. Curr. Med. Chem. 2011, 18, 1993-2015. [CrossRef]

3. Janas, J.; Przybylski, P. 14- and 15-membered lactone macrolides and their analogues and hybrids: Structure, molecular mechanism of action and biological activity. Eur. J. Med. Chem. 2019, 182, 111662. [CrossRef]

4. Morimoto, S.; Takahashi, Y.; Watanabe, Y.; Omura, S. Chemical modification of erythromycins. I. Synthesis and antibacterial activity of 6-0-methylerythromycins A. J. Antibiot. 1984, 37, 187-189. [CrossRef] [PubMed]

5. Djokić, S.; Kobrehel, G.; Lazarevski, G.; Lopotar, N.; Tamburašev, Z.; Kamenar, B.; Nagl, A.; Vicković, I. Erythromycin series. Part 11. Ring expansion of erythromycin A oxime by the Beckmann rearrangement. J. Chem. Soc. Perkin Trans. 1 1986, 1881-1890. [CrossRef]

6. Zhanel, G.G.; Walters, M.; Noreddin, A.; Vercaigne, L.M.; Wierzbowski, A.; Embil, J.M.; Gin, A.S.; Douthwaite, S.; Hoban, D.J. The Ketolides. Drugs 2002, 62, 1771-1804. [CrossRef]

7. Wu, Y.-J. Highlights of Semi-synthetic Developments from Erythromycin, A. Curr. Pharm. Des. 2000, 6, 181-223. [CrossRef] [PubMed]

8. Wang, G.; Niu, D.; Qiu, Y.-L.; Phan, L.T.; Chen, Z.; Polemeropoulos, A.; Or, Y.S. Synthesis of Novel 6,11-O-Bridged Bicyclic Ketolides via a Palladium-Catalyzed Bis-allylation. Org. Lett. 2004, 6, 4455-4458. [CrossRef]

9. Keyes, R.F.; Carter, J.J.; Zhang, X.; Ma, Z. Short and Efficient Synthesis of a Vinyl-Substituted Tricyclic Erythromycin Derivative. Org. Lett. 2005, 7, 847-849. [CrossRef] [PubMed]

10. Gai, Y.; Tang, D.; Xu, G.; Chen, Z.; Polemeropoulos, A.; Wang, Z.; Or, Y.S. Synthesis of 3,6-bicyclolides: A novel class of macrolide antibiotics. Bioorg. Med. Chem. Lett. 2008, 18, 6315-6318. [CrossRef] 
11. Tang, D.; Gai, Y.; Polemeropoulos, A.; Chen, Z.; Wang, Z.; Or, Y.S. Design, synthesis, and antibacterial activities of novel 3,6bicyclolide oximes: Length optimization and zero carbon linker oximes. Bioorg. Med. Chem. Lett. 2008, 18, 5078-5082. [CrossRef] [PubMed]

12. Kanoh, S.; Rubin, B.K. Mechanisms of Action and Clinical Application of Macrolides as Immunomodulatory Medications. Clin Mibrobiol. Rev. 2010, 23, 590-615. [CrossRef] [PubMed]

13. Muralidharan, V.; Striepen, B. Teaching old drugs new tricks to stop malaria invasion in its tracks. BMC Biol. 2015, 13, 72. [CrossRef] [PubMed]

14. Parnham, M.J.; Haber, V.E.; Giamarellos-Bourboulis, E.J.; Perletti, G.; Verleden, G.M.; Vos, R. Azithromycin: Mechanisms of action and their relevance for clinical applications. Pharmacol. Therapeut. 2014, 143, 225-245. [CrossRef]

15. Echeverría-Esnal, D.; Martin-Ontiyuelo, C.; Navarrete-Rouco, M.E.; De-Antonio Cuscó, M.; Ferrández, O.; Horcajada, J.P.; Grau, S. Azithromycin in the treatment of COVID-19: A review. Exp. Rev. Antiinfect. Ther. 2020, 19, 147-163. [CrossRef]

16. Shapovalova, E.N.; Fedorova, I.A.; Anan'eva, I.A.; Shpigun, O.A.J. Macrocyclic Antibiotics as Chiral Selectors in HighPerformance Liquid Chromatography and Capillary Electrophoresis. Anal. Chem. 2018, 73, 1064-1075.

17. Nicolaou, K.C.; Bulger, P.G.; Sarlah, D. Palladium-Catalyzed Cross-Coupling Reactions in Total Synthesis. Angew. Chem. 2005, 117, 4516-4563, Angew. Chem. Int. Ed. 2005, 44, 4442-4489. [CrossRef]

18. Trost, B.M.; Crawley, M.L. Asymmetric Transition-Metal-Catalyzed Allylic Alkylations: Applications in Total Synthesis. Chem. Rev. 2003, 103, 2921-2943. [CrossRef]

19. Stoner, E.J.; Peterson, M.J.; Allen, M.S.; DeMattei, J.A.; Haight, A.R.; Leanna, M.R.; Patel, S.R.; Plata, D.J.; Premchandran, R.H.; Rasmussen, M. Allylation of Erythromycin Derivatives: Introduction of Allyl Substituents into Highly Hindered Alcohols. J. Org. Chem. 2003, 68, 8847-8852. [CrossRef]

20. Trost, B.M.; Machacek, M.R.; Aponick, A. Predicting the Stereochemistry of Diphenylphosphino Benzoic Acid (DPPBA)-Based Palladium-Catalyzed Asymmetric Allylic Alkylation Reactions: A Working Model. Acc. Chem. Res. 2006, 39, 747-760. [CrossRef] [PubMed]

21. Henninger, T.C.; Macielag, M.J.; Tennakoon, M.A.; Xu, X. Preparation of 6-O-acyl Ketolide Derivatives of Erythromycin Useful as Antibacterials. WO2003050132A1, 19 June 2003.

22. Fakhfakh, M.A.; Fournet, A.; Prina, E.; Mouscadet, J.-F.; Franck, X.; Hocquemiller, R.; Figaderea, B. Synthesis and Biological Evaluation of Substituted Quinolines: Potential Treatment of Protozoal and Retroviral Co-infections. Bioorg. Med. Chem. 2003, 11, 5013-5023. [CrossRef]

23. Wilkening, R.R.; Ratcliffe, R.W.; Doss, G.A.; Mosley, R.T.; Ball, R.G. Novel Transannular Rearrangements of Azalide Iminoethers. Tetrahedron 1997, 53, 16923-16944. [CrossRef]

24. Everett, J.R.; Tyler, J.W. An Analysis of the ${ }^{1} \mathrm{H}$ and ${ }^{13} \mathrm{C}$ n.m.r. spectra of erythromycin a using two-dimentional methods. J. Chem. Soc. Perkin Trans. 1 1985, 2599-2603. [CrossRef]

25. Lazarevski, G.; Vinković, M.; Kobrehel, G.; Đokić, S.; Metelko, B.; Vikić-Topić, D. Conformational Analysis of Azithromycin by Nuclear Magnetic Resonance Spectroscopy and Molecular Modelling. Tetrahedron 1993, 49, 721-730. [CrossRef]

26. Nakagawa, Y.; Chanthamath, S.; Shibatomi, K.; Iwasa, S. Ru(II)-Pheox-Catalyzed Asymmetric Intramolecular Cyclopropanation of Electron-Deficient Olefins. Org. Lett. 2015, 17, 2792-2795. [CrossRef]

27. Or, Y.S.; Phan, T.; Wang, G.; Wang, Y.; Peng, Y. Preparation of 9A,11-2C-bicyclic 9a-azalide Erythromycin Derivatives as Prodrugs and Antibacterial Agents. U.S. Patent US20060154881A1, 13 July 2006.

28. Clinical and Laboratory Standards Institute. Performance standards for Antimicrobial Susceptibility Testing; 15th Informational Supplement; CLSI document M100-S15; Clinical and Laboratory Standards Institute: Wayne, PA, USA, 2005. 